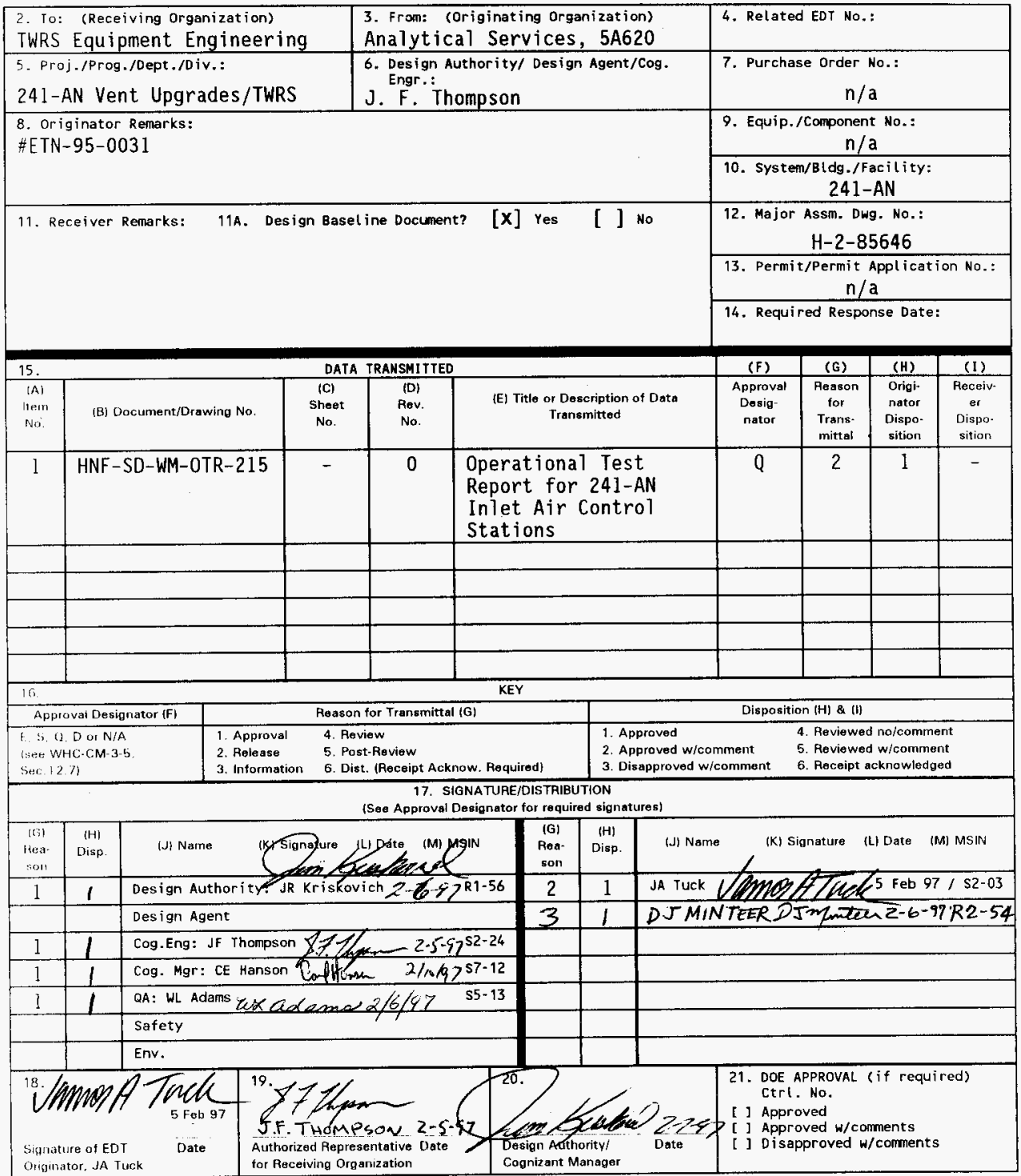

$\mathrm{BD} \cdot 7400-172-2(05 / 96)$ GEF097 


\title{
Operational Test Report for 241-AN Primary Tank Inlet Air Control Stations
}

\author{
J.A. TweK
}

Fluor-Daniel Hanford Co., Richland, WA 99352

U.S. Department of Energy Contract DE-ACO\&-96RL13200

EDT: 617371

Org Code: 5 A620

B\&R Code: EW3120071
UC: 506

Charge Code: E20882/P5A400

Total Pages: 6 '

Key Words: ventilation, upgrades, flow control, primary confinement, nuclear air treatment, aerosol testing, ASME N510

Abstract: This is the operational test report for 241-AN Tank Farm primary ventilation system inlet air filter and control stations, following their installation in the field and prior to their acceptance for beneficial use.

TRADEMARK DISCLAIMER. Reference herein to any specific commercial product, process, or service by trade name, trademark, manufacturer, or otherwise, does not necessarily constitute or imply its endorsement, recomendation, or favoring by the United states Goverment or any agency thereof or its contractors or subcontractors.

Printed in the United States of America. To obtain copies of this document, contact: WHC/BCS Document Control Services, P.O. Box 1970, Mailstop H6-08, Richland WA 99352, Phone (509) 372-2420; Fax (509) 376-4989.
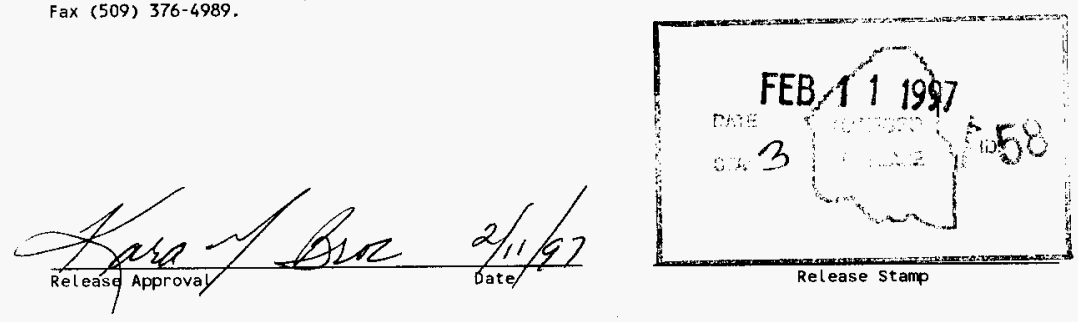

\section{Approved for Public Release}




\section{HNF-SD-WM-0TR-215 Rev. 0 \\ OPERATIONAL TEST REPORT FOR 241-AN TANK FARM \\ INLET AIR CONTROL STATIONS}

\section{CONTENTS}

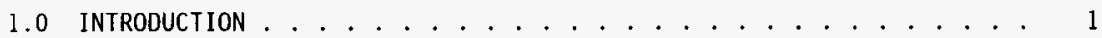

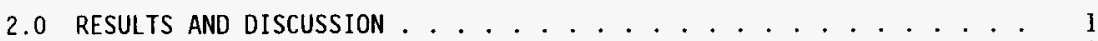

2.1 INITIAL SYSTEM BALANCING . . . . . . . . . . . . . 1

2.2 AIR FLOW CONTROLLER FUNCTIONAL TEST .......... 2

2.3 VAPOR MONITORING AND EQUIPMENT BONDING .......... 2

2.4 AEROSOL PENETRATION TEST ............... 2

2.5 SYSTEM RESTORATION . . . . . . . . . . . . . . 3

2.6 TEST EXCEPTIONS AND POST TESTING . . . . . . . . . . . . . . 4

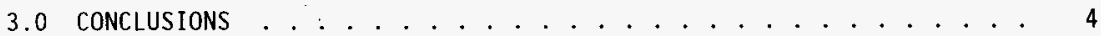

4.0 ReCOMMEndATIONS . . . . . . . . . . . . . . . . . . . . . . 4

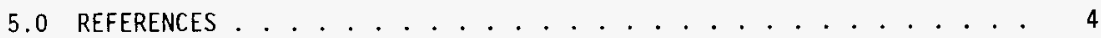

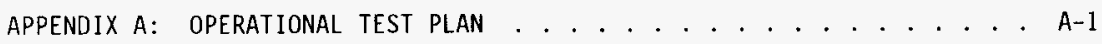

FIGURE 1. INLET FILTER TEST PORTS (TYPICAL) . . . . . . . . . . A-13

APPENDIX B: TEST DATA SHEETS AND PARTICIPANTS LIST . . . . . . . . . . B-1 


\subsection{INTRODUCTION}

Tank inlet air control and filter stations (see Fig. 1, App. A) were installed to enhance ventilation control capability in the 24l-AN tank farm (WHC 1996a). The air control stations are intended to be the primary air flow paths into the waste tanks, providing a new capability for maintaining an easily set and verifiable air flow rate into each waste tank. The air control stations can also be used to maintain tank vacuum at prescribed levels. In addition, each station acts as a filtered, pressure relief for the tank air space. The air control stations are completely system-operated (i.e., no external power sources needed).

The stations were installed on the seven waste tanks in 0ctober 1996 and January 1997. Acceptance testing was completed in January 1997 (FDHC 1997). On 28 January 1997 the operational test was performed. The test procedure (Tuck 1996a) consisted primarily of a simple functional test of each station's air flow controller, aerosol testing of each station's high efficiency particulate air (HEPA) filter, and ventilation system balancing (i.e., tank air flows and vacuum level) using the air control stations.

The Test Director for the operational test was Greg Hanson, of East Tank Farms Engineering, Lockheed-Martin Hanford Company (LMHC). The Person-inCharge (PIC) for the operational test was James $T$. Ross, of East Tank Farms Operations, Lockheed-Mart in Hanford Company (LMHC). The cognizant engineer for the operational test was Jack Thompson of SESC Equipment Engineering. The cognizant engineer for 241-AN Tank Farm, Bob Nicholson of East Tank Farms Engineering, LMHC, was also present. Additional field support during testing was provided by East Tank Farms Operations, Vent and Balance, and Dan Minteer (Engineer, Duke Engineering Services Hanford Company). A reprint of the operational test plan (OTP), including the test procedure, is attached as Appendix $A$ of this report. Test data sheets are attached as Appendix $B$. The Unreviewed Safety Question Screening tracking number for the operational test is TF-96-0084 Rev. 2.

\subsection{RESULTS AND DISCUSSION}

The air control stations were successfully tested in accordance with the OTP and shown to be ready for service. Actual recorded field data, notes, and observations are presented in Appendix $B$ of this report. The following is a summary of results, arranged by corresponding sections of the OTP.

\subsection{INITIAL SYSTEM BALANCING}

Pit covers were opened and vapor monitoring was successfully completed, with acceptable measured levels of gas and oxygen. The primary vent valves were opened or verified as open. Tank pressure was monitored directly, during testing, from riser-mounted gauges WST-PI-101 through WST-PI-107. Average tank vacuum level was approximately 2 in. w.g. at the start of testing, and recorded tank vacuum levels ranged from 1.5 to 3.0 in. w.g. during the course of testing (ref. OTP data sheets, Appendix B). 


\subsection{AIR FLOW CONTROLLER FUNCTIONAL TEST}

The air flow controller is "powered" by the air flowing through it. It is set by installing an orifice plate of known performance characteristics. Any variance in set air flow (i.e., caused by a change in tank vacuum or atmospheric pressure changes) will cause an automatic and immediate adjustment to the size of an internal flow area to return flow to the set point. Thus, the flow rate through one air flow controller can be adjusted without affecting the flow through any of the other air flow controllers. This flow control concept, and the capability of actual units, have been previously demonstrated through testing (Tuck 1996b \& 1996c). Orifice sizes and their corresponding nominal flow rates are tabulated elsewhere (WHC 1996b).

The air flow controller is equipped with a view port to allow for visual verification that the set flow rate is occurring. Various visual inspections were the essence of the OTP's simple functional test. See the OTP in Appendix A for more details. All six air flow controllers were verified to be functional and operating at the set flow.

\subsection{VAPOR MONITORING AND EQUIPMENT BONDING}

Equipment bonding and vapor monitoring were performed in accordance with the OTP and facility procedural requirements relative to flammable gas. All bonding assemblies met the specified 1-M $\Omega$ resistance criterion. All recorded flammable gas readings were zero ( $0 \% \mathrm{LEL})$.

\subsection{AEROSOL PENETRATION TEST}

The HEPA filter aerosol test is a standard in-place test used to verify the integrity of the filter media, frame, and seal. The HEPA filters, rated at $500 \mathrm{ft}^{3} / \mathrm{min}$, were tested at $125 \mathrm{ft}^{3} / \mathrm{min}$ using an onsite standard maintenance procedure $(6-T F-156)$. The acceptance criteria for this test was that the calculated aerosol penetration, for each of three trials, must be less than $0.05 \%$. The results are tabulated below. All filters passed all test trials.

\begin{tabular}{|c|c|c|c|c|c|}
\hline $\begin{array}{c}\text { Tank } \\
\text { Number } \\
241-A N-\end{array}$ & $\begin{array}{c}\text { Test Flow } \\
\text { Rate } \\
\text { (\% of } \\
\text { Rated) }\end{array}$ & $\begin{array}{c}\% \\
\text { Penetration } \\
\text { Trial 1 }\end{array}$ & $\begin{array}{c}\% \\
\text { Penetration } \\
\text { Trial 2 }\end{array}$ & $\begin{array}{c}\% \\
\text { Penetration } \\
\text { Trial 3 }\end{array}$ & $\begin{array}{c}\text { Pass } \\
\text { or } \\
\text { Fail }\end{array}$ \\
\hline \hline 101 & 25 & .002 & .002 & .002 & PASS \\
\hline 102 & 25 & .002 & .002 & .002 & PASS \\
\hline 103 & 25 & .002 & .002 & .002 & PASS \\
\hline 104 & 25 & .002 & .002 & .002 & PASS \\
\hline 105 & 25 & .002 & .002 & .002 & PASS \\
\hline 106 & 25 & .002 & .002 & .002 & PASS \\
\hline 107 & 25 & .002 & .002 & .002 & PASS \\
\hline
\end{tabular}




\subsection{SYSTEM RESTORATION}

Prior to installing the air control stations, air entered each waste tank primarily through the pump and valve pit cover blocks; their edges, seams, access plates, and valve handle penetrations. The pump and valve pits contain drain lines or other apertures which are in direct connection with the tank vapor spaces. Maintaining control of the numerous tank air inleakage paths was a problem in itself. With the multi-tank/single-fan arrangement, individual tank air flow control was nearly impossible.

The reduction of tank air inleakage (or any other ventilation system inleakage) plays a key role in maximizing the capabilities of the air control stations (i.e., the ability to control higher air flow rates and/or allow greater tank vacuum levels). Any residual difference between the sum of the nominal tank flow rates and a measured exhaust stack flow rate will depend upon how much other ventilation system or tank inleakage still exists. Drains in the pump and valve pits were identified as possible major sources of tank inleakage and were closed prior to the operational test. No additional sealing efforts were made in the course of running the OTP.

Special gaskets, per ECN 634901 (ref. H-2-71986 \& H-2-90172) are available for installation in the valve handle penetrations in the various pit cover blocks to further reduce tank air inleakage.

After the aerosol penetration tests (Sec. 2.4, OTP) were completed, as part of system restoration, ventilation system balancing was achieved by simply installing an orifice plate of known flow performance into each air flow controller, which set each tank to a desired air flow apportionment. The table below shows the orifice sizes and set tank flow rates at the completion of the 0TP. The air control stations on the three watchlist tanks (AN-103, -104 , and -105 ) were left on line while the remaining 4 air stations were isolated until additional tank sealing could be accomplished.

\begin{tabular}{|c|c|c|}
\hline \multirow{2}{*}{ Tank Number 241-AN- } & \multicolumn{2}{|c|}{ Final Orifice Installed } \\
\cline { 2 - 3 } & Size, in. & Nominal Flow Rate, $\mathrm{ft}^{3} / \mathrm{min}$ \\
\hline 101 & $2-7 / 16$ & $60^{\star}$ \\
\hline 102 & $2-7 / 16$ & $60^{\star}$ \\
\hline 103 & $3-3 / 32$ & $100^{*}$ \\
\hline 104 & $3-3 / 32$ & $100^{\star}$ \\
\hline 105 & $3-3 / 32$ & $100^{*}$ \\
\hline 106 & $2-7 / 16$ & $60^{\star}$ \\
\hline 107 & $2-7 / 16$ & $60^{\star}$ \\
\hline
\end{tabular}

* The verifiable, minimum tank ventilation rate (does not include tank inleakage), which is regulated by the set air flow controller as a function of the installed orifice size. 


\subsection{TEST EXCEPTIONS AND POST TESTING}

No test exceptions were found in the course of testing. Data sheets were completed and were reviewed by Quality Assurance at the conclusion of testing.

\subsection{CONCLUSIONS}

An operational test of the newly installed air control stations in 241-AN Tank Farm was successfully completed, without exceptions. The systems are in service or are ready to be placed in service at the discretion of East Tank Farms Operations.

The air control stations make it possible to balance the ventilation system (i.e., tank flows and vacuum level) and maintain constant minimum tank flows by simply installing an orifice plate of known flow performance into each air flow controller. Orifice plate nominal flow ratings are given on the air flow controller drawing $\mathrm{H}-2-85647$ (WHC 1996b). The set flow rate through one air flow controller can be changed, within system (e.g., fan) limitations, without affecting the flow through any of the other air flow controllers.

Tank vacuum levels can be easily manipulated for work activities (i.e., opening a riser) by temporarily isolating one or more air control stations. Note that all of the tank vacuum levels will be slightly affected by this action. Air flows through other air control stations will not be affected.

The proper operation of each air control station can be quickly and easily verified by performing a simple visual inspection of the air flow controller. This visual inspection and functional check is referenced in Operating Procedure T0-060-101.

Although tank air inleakage was reduced by sealing per Sec. 2.0 of the OTP, some tank inleakage was still apparent at the conclusion of testing and efforts are ongoing to seal remaining inleakage paths. The pump and valve pit cover blocks are possible sources of tank inleakage. Drains in these pits were closed prior to the operational test. Additional tank sealing efforts are continuing.

\subsection{RECOMMENDATIONS}

Though tank air inleakage has been significantly reduced, other sources of ventilation system or tank inleakage still may yet exist following testing. This inleakage should be verified from stack flow measurements, located, and further reduced to allow full benefit of the air control stations' capabilities.

\subsection{REFERENCES}

[See Appendix A of this document for additional references.]

FDHC, 1997, Acceptance Test Report, Inlet Air Filter and Control Station Pressure Decay Test, WHC-SD-WM-ATR-177 Rev 0, Fluor-Daniel Hanford Company, Richland, Washington 
Tuck, 1996a, Operational Test P7an for 241-AN Tank Inlet Air Control Stations, WHC-SD-WM-OTP-215 Rev 1, Westinghouse Hanford Company, Richland, Washington

Tuck, 1996b, Test Report, Constant Air Flow Control Device for Tank Farm Ventilation Systems, WHC-SD-WM-TRP-247 Rev 0-A (incl. original Rev. 0), West inghouse Hanford Company, Richland, Washington

Tuck, 1996c, Acceptance Test Report, Flow Controller and Vacuum Breaker Assemblies, WHC-SD-WM-ATR-178 Rev 0, Westinghouse Hanford Company, Richland, Washington

WHC, 1996a, Air Control Station, H-2-85646 Rev 0, Westinghouse Hanford Company, Richland, Washington

WHC, 1996b, Airflow Controller, H-2-85647 Rev 0, Westinghouse Hanford Company, Richland, Washington 


\section{APPENDIX A: OPERATIONAL TEST PLAN FOR 241-AN TANK FARM INLET AIR CONTROL STATIONS, WHC-SD-WM-OTP-215 (REPRINTED)}

\subsection{INTRODUCTION}

\subsection{PURPOSE AND SCOPE}

This document is the Operational Test Plan for waste tank inlet air control stations for 241-AN, and includes an Operational Test Procedure (OTP). The inlet air control stations include a Flow Controller Assembly (a passively operated, air flow control device) and a HEPA filter housing.

NOTE, this document IS NOT a plant operating or maintenance procedure. All operator actions are intended to be performed per valid, approved procedures or work control documents, as appropriate, in accordance with the requirements of Tank Farm Transition Projects.

The scope of this OTP will be to verify that the inlet air control stations operate in accordance with the design requirements. Specifically, the following items will be verified on each inlet air control station prior to final acceptance for use in the 241-AN Tank Farm:

- Operation of the Flow Controller Assembly.

- Ability to perform in place aerosol testing of the inlet air control station HEPA filter.

\subsection{PERSONNEL AND RESPONSIBILITIES}

Person In Charge (PIC)

- Ensures that personnel and equipment are scheduled and materials are obtained as required for this OTP.

- Is responsible for personnel safety during performance of the test.

Test Director

- Is the single person in charge during testing and determines when testing is, or is not, in progress.

- Directs the test personnel and test activities.

- Reviews and approves exceptions to the OTP.

- Witnesses and initials each step of the 0TP, or designates a responsible person to do so.

\section{Cognizant Engineer}

- Represents TWRS Equipment Engineering.

- Prepares the OTP document and revisions.

- Prepares or assists in preparing exceptions to the OTP.

- Appoints a Test Director.

- Provides technical support as required during the OTP.

- Approves acceptability of test activities and results.

- Prepares the Operational Test Report (OTR) and revisions. 
Vent \& Balance

- Performs in place aerosol test of HEPA filter.

Quality Assurance

- Quality Assurance reviews data sheets for completeness and legibility (post testing).

- Quality Control verifies electrical bonding if required by procedures, or as requested by Operations or the Cog. Engineer.

Safety Assurance

- Inspects test equipment or facilities, if requested, to resolve safety concerns.

Operations

- Provides support for field preparation and execution of OTP.

- Performs all ventilation system adjustments required by OTP.

Health Physics Technician

- Provides support for field preparation and execution of OTP.

- Performs monitoring as required.

\subsection{TEST EQUIPMENT REQUIRED}

\section{NOTE}

A11 Measuring and Test Equipment (M\&TE) used to perform this work must be within its current calibration cycle as shown on the calibration label.

Testing shall be conducted in 241-AN Tank Farm. No special prerequisites are placed on air temperature and pressure. Required test equipment includes:

- Inlet air control stations installed in 241-AN (ref. H-2-85646)

- Prefilter and HEPA filter installed in filter housings

- Standard pitot tube, as necessary

- Aerosol probe

- Aerosol (DOE-approved)

- Aerosol generator (must produce acceptable aerosol)

- Manometer or similar airflow equipment, as necessary

- Photometer 
HNF-SD-WM-0TR-215 Rev. 0

- Materials for sealing tank air infiltration paths (tape, gaskets, other sealing media, etc.).

- Materials for electrical bonding per Sec. 2.3 of this document.

\subsection{PRECAUTIONS AND LIMITATIONS}

1.4.1 Facility safety rules and Radiation Work Permits (RWPs) shall be reviewed before performing this work.

1.4.2 Comply with WHC and facility specific lock and tag or overtagging requirements, as applicable.

1.4.3 If any waste is generated during performance of this work, consult Facility Hazardous Waste Coordinator for specific instructions to ensure compliance with WHC and DOE environmental standards, as applicable, for disposal.

1.4.4 Take special care to ensure contamination control when inserting and withdrawing vent and balance equipment.

1.4.5 Only Department of Energy (DOE) approved aerosols shall be used to perform this work (e.g., Emery 3004).

1.4.6 Don air purifying respirator fitted with HEPA filters if there is reason to suspect leakage of aerosol into breathing zone of employees.

1.4.7 If any of the following conditions are found when performing this work, stop work immediately, place equipment in a safe condition, and notify Facility Person In Charge (PIC):

- Facility equipment malfunction.

- Personnel error or procedure inadequacy that prevents fulfillment of procedure requirements.

- Any condition which potentially affects worker health or safety.

1.4.8 All work must be done in accordance with OSD-00007 and OSD-00030 as applicable.

\subsection{PREREQUISITES}

1.5.1 Notify Operations Shift Manager before performing this work.

1.5.2 Facility PIC shall perform a pre-job safety meeting and Job Hazard Analysis, including all involved personnel, per WHC-CM-1-10, Safety Manual. Standard WKS-6, "Pre-job Safety Planning".

1.5.3 Any necessary ventilation pit equipment connections (including bonding) may be made prior to running this OTP to allow for vapor sampling during this 0TP (without the need to reenter a 
HNF-SD-WM-0TR-215 Rev. 0

ventilation pit if possible). Monitoring shall be in accordance with OSD-T-151-00007 and 0SD-T-151-00030 as applicable.

1.5.4 If potential for radiological contamination exists, request HPT perform equipment survey prior to maintenance or removal of equipment from installed location.

1.5.5 Verify that the four differential pressure gauges on each inlet air control station (seven stations total, one per tank) are calibrated.

1.5.6 Verify that pressure decay test (ref. WHC-SD-WM-ATP-177) has been completed.

\subsection{SYSTEM DESCRIPTION}

\section{General}

Each of the seven 241-AN waste tanks has an inlet air control station connected to a dedicated tank riser. See drawings H-2-71991 through -71996, and $\mathrm{H}-2-72039$, for installation locations.

The inlet air control station is intended to be the primary path through which air can enter the waste tank. The purpose of the inlet air control station is to enhance tank air flow and tank vacuum control capability, and to provide a filtered pathway for air to exit each tank should tank pressure(s) exceed atmospheric pressure (i.e., if active ventilation is lost or during a gas release from the waste).

Figure 1 of this 0TP shows the general design and equipment arrangement; see drawing H-2-85646 for equipment design details. Primary components of each inlet air control station include, in order of inward flow, an air flow controller, a test section, a prefilter, a HEPA filter, a flex connection, and a 12 -in. isolation butterfly valve (normally open), with interconnecting duct transitions as needed. The inlet air control station connects to the tank riser at the 12-in. isolation valve. A vacuum breaker is connected in parallel with the flow controller to limit tank negative pressure in the event that flow control capability is lost.

An alternate tank air inlet, or filter bypass line, is connected in parallel with each inlet air control station for use during maintenance or in the event that the normal ventilation path becomes obstructed.

\section{Air Flow Controller}

The air flow controller (ref. $\mathrm{H}-2-85647$ ) is an automatic, passively operated device which does not require electrical power or control instrumentation. It has a single moving part (called the Port Controller) which floats inside a stainless steel housing. Air enters the bottom of the housing through a coarse filter. Each air flow controller can be set to control nominal flow rate from $50 \mathrm{cfm}$ to $500 \mathrm{cfm}$. Air flow rate setting can be easily adjusted in the field. Operation of the flow controller is verified by observing levitation of the Port Controller, which is visible through a view port in the housing. 
For each air flow controller to have the maximum possible operating range, ventilation system and tank air inleakage paths must be reduced as much as possible. In addition, ventilation system pressure losses (i.e., from dampers, dirty filters, etc.) must be kept to a minimum.

\section{Vacuum Breaker}

The vacuum breaker is an automatic, passively operated device which does not require electrical power or control instrumentation (essentially a weighted damper capable of keeping a constant pressure drop). It is constructed primarily of stainless steel. The vacuum breaker is installed in parallel with the flow controller on each tank inlet, preset to actuate at a differential pressure of 3.3 in. w.g. The vacuum breaker is designed to 1 imit tank negative pressure in the event that air flow through any combination of the seven air flow controllers becomes significantly restricted. If necessary (i.e., due to ice formation), the vacuum breaker relief port may be manually actuated. The vacuum breaker can be easily removed in the field and set to a new actuation point if necessary (ref. H-2-85647).

\section{Test Section}

The test section is a section of duct between the air flow controller and the filter housings, and provides the location for an aerosol injection port for the purpose of testing the HEPA filter (ref. $\mathrm{H}-2-85646-8$, al so port " $A$ " on Figure 1 of this document).

\section{Filters and Filter Housing}

The HEPA filter is $24 \times 24 \times 5-7 / 8$ in., rated for $500 \mathrm{cfm}$ at $1 \mathrm{in}$. w.g., and is mounted together with a $24 \times 24 \times 4$ in. prefilter in the manufacturer's standard stainless steel housing (ref. H-2-85646-17, $-18, \&-19$ ).

\section{Differential Pressure Indicators}

There are four differential pressure indicators on each inlet air control station to provide status of filters and flow controller performance. These are labeled VTP-PDI-112 through -115 (see P\&ID drawing H-14-020101). Each gauge number has a letter suffix $A$ through $G$ corresponding to tanks 241-AN-101 through 24l-AN-107, respectively (e.g., VTP-PDI-112A through -115A for $A N-101)$. Gauges $-112,-113$, and -114 are mounted on a common rack over the fi]ter housing (ref. H-2-85646-5\&-20). Gauge -115 is mounted on the air flow controller (ref. H-2-85647).

\section{NOTE}

The sum of readings from gauges $-112,-113$, and -114 is approximately equal to corresponding tank negative pressure (for information only).

- VTP-PDI-112A (through-112G): This gauge indicates the differential pressure across the air flow controller (the gauge's high pressure port is open to atmospheric pressure). Normal air flow controller differential pressure readings are from 0.3 in. $w . g$. to the vacuum breaker set point. 
- VTP-PDI-113A (through -113G): This gauge indicates the differential pressure across the pre-filter located inside the HEPA filter housing. Normal prefilter differential pressure readings are from 0 to 1 in. w.g.

- VTP-PDI-114A (through -114G): This gauge indicates the differential pressure across the HEPA filter. Filters are rated for a 1 in. w.g. pressure drop at $500 \mathrm{cfm}$. Normal HEPA filter differential pressure readings are from 0.1 and $2.0 \mathrm{in.}$ w.g.

- VTP-PDI-115A (through -115G): This gauge indicates the differential pressure across some of the air flow controller's internal components (including its inlet screens and filter media). The gauge's high pressure port is open to atmospheric pressure. Readings from this gauge provide an early indication of screen or filter blockage, flow controller blockage or malfunction. Normal component differential pressure readings are from 0.3 to 1.0 in. w.g.

\section{Filter Bypass Line}

A 3 -in. bypass line containing an orifice plate and 3 -in. ball valve is connected to the tank riser in parallel with the inlet air control station. The orifice is designed to allow controlled air flow into the tank as needed to maintain air flow and tank negative pressure during maintenance or in the event that the normal air path becomes obstructed (ref. H-2-85646-4).

\subsection{TEST EXECUTION AND TEST EXCEPTIONS}

Testing shall be conducted by the responsible personnel as defined in this OTP. Blank field copies of the test data sheets shall be obtained for the operational test; one set shall be provided for each tank.

The Test Execution Data Sheet has an ACCEPT/REJECT box for each step of the OTP. The test director or designee shall initial and date each step as it is completed. This signifies that the step has been successfully completed according, with the required data recorded in the adjacent data and observations column, including units of measure where applicable, and acceptance criteria (if any) having been met.

The order in which the installations are tested is determined by the Test Director. Record the corresponding tank number on each set of data sheets. In addition, at the direction of the Test Director, steps or subsections within Sec. 2.0 may be performed in an order other than given.

Test exceptions shall be resolved during testing. Each exception and its resolution shall be documented on a copy of the Record of Test Exception sheet provided; one sheet per exception. Exceptions shall also be referenced in the COMMENTS column of Test Execution Data Sheet at the corresponding OTP step.

If an exception requires equipment adjustment or modification, or the Test Director determines continued operation may result in an unsafe situation, the equipment should be shut down and placed in a safe condition, and testing suspended. Testing shall be resumed by the Test Director only after the exception is resolved and documented, at a logical starting point that will provide retesting of the item that initiated the exception or concern. 
Test exceptions are normally prepared by the Cognizant Engineer, but may be prepared by the Test Director or others with the technical assistance and approval of the Cognizant Engineer. Exceptions shall be approved by the Test Director and Cognizant Engineer.

This OTP, along with the notated data sheets (including test exceptions), shall be used in compiling a test report, released as a Supporting Document.

\subsection{OPERATIONAL TEST PROCEDURE (OTP)}

\section{NOTE}

At any step of the OTP, the Test Director or designee may request that the exhauster stack flow per procedure 7-GN-056, the on-line exhauster's filter and deentrainer differential pressures, or tank pressure be measured.

Record measurement on the data sheets at the current step.

\section{NOTE}

Tank sealing efforts (ref. procedure T0-060-101) may continue as necessary throughout the remainder of this OTP, provided tank vacuum levels do not exceed 3.3 in. w.g. If the vacuum level in any tank exceeds 3.3 in. w.g., terminate sealing efforts. Remove sealing material as necessary on untested tanks to keep vacuum level below 3.3 in. w.g., or adjust flow rate on previously tested units by changing flow controller orifice plate.

\subsection{INITIAL SYSTEM BALANCING}

\section{NOTE}

Figure 1 and test data sheets follow Section 3.0. Valve and vent pit numbers are identified on P\&ID for 241-AN, drawing H-14-020101.

2.1.1 Open hinged vent pit covers as required (4 total):

VENT PIT-101 $\approx$ TANKS AN-102 \& AN-103
VENT PIT-102 $\approx$ TANKS AN-101 \& AN-104
VENT PIT-103 $\approx$ TANKS AN-105 \& AN-106
VENT PIT-104 $\approx$ TANK AN-107

2.1.2 Monitor for toxic gases, flammable gases and oxygen deficiencies before pit entry. A Confined Space Entry Permit shall be required for al1 pit entries.

2.1.3 Enter each pit (metal ladders and lights are permanently installed in these pits) and open each 12-in. (upper) primary vent valve or verify valve is open ( 7 total) as fully as possible in accordance with Sec. 5.2 of procedure T0-060-101.

VENT PIT-101 $\approx$ TANKS AN-102 \& AN-103 $\approx$ VALVES V-132 \& V-133
VENT PIT-102 $\approx$ TANKS AN-101 \& AN-104 $\approx$ VALVES V-131 \& V-134
VENT PIT-103 $\approx$ TANKS AN-105\&AN-106 $\approx$ VALVES V-135 \& V-136
VENT PIT-104 $\approx$ TANK AN-107


2.1.4 Record tank pressures (i.e., vacuum levels) on all 7 tanks.

2.1.5 If necessary to remove lock \& tag from the 12-in. inlet isolation valve (physically labeled VTP-V-154A for tank 241-AN-101 through -154G for tank 241-AN-107), contact the shift manager.

\section{NOTE}

At the direction of the Test Director, any one or more of the isolation vaives, previously opened on other tanks per Step 2.1.6, may be closed at any time during the OTP as necessary for tank vacuum control, or flow rates on previously tested units adjusted by changing flow controller orifice plates.

2.1.6 Open the inlet 12-in. isolation butterfly valve to bring the inlet air control station on 1 ine per T0-060-101.

2.1.7 If directed by the Test Director, repeat steps 2.1 .5 and 2.1 .6 for some or all of the remaining tanks, in the order specified by the Test Director.

2.1.8 If directed by the Test Director, the orifice plates in any or all of the flow controllers may be changed per T0-060-101 to optimize tank flow rates. If changed, record tank numbers, orifice ID size and corresponding nominal flow rate as given on $\mathrm{H}-2-85647$, and tank pressure after it stabilizes.

\subsection{AIR FLOW CONTROLLER TEST}

2.2.l Ensure that a 3.5-in. ID orifice plate (corresponds to $125 \mathrm{ft}^{3} / \mathrm{min}$; ref. drawing $\mathrm{H}-2-85647$ ) is installed in the flow controller, or install one per T0-060-101.

\section{NOTE}

The air flow controller (ref. H-2-85647) contains a 3-in. diameter view port, through which the top portion of the device's moving part (a 6-in. diameter cylinder called the Port Controller) may be seen. There is a narrow black ring painted around the top of the cylinder. If the air flow is below the set flow rate or if there is no flow, the Port Controller will be resting down on its stop and only this black ring will be visible. In normal operation ( $i . e$. , when the set flow rate is occurring), the Port Controller floats above its resting position and a portion of the unpainted outer surface of the cylinder is visible below the painted ring. Usually, a slight buoyant action can also be observed, indicating that the port controller is not stuck.

2.2.2 Verify that the Port Controller is levitated above its resting position (see NOTE above).

2.2.3 Perform the following steps, as required, to verify that the Port Controller is not stuck (i.e., due to ice or debris buildup or other damage) or to verify that it travels freely between its current position and its resting position. 
HNF-SD-WM-0TR-215 Rev. 0

2.2.4 Close the inlet air control station's 12-in. isolation butterfly valve (physically labeled VTP-V-154A for tank 241-AN-101 through -154G for tank 241-AN-107) (ref. T0-060-101) while observing that the Port Controller drops freely to its resting position.

2.2.5 0pen the 12-in. isolation butterfly valve that was closed in the previous step while observing that the Port Controller raises freely to its initial position.

\subsection{VAPOR MONITORING AND EQUIPMENT BONDING}

NOTE

OSD's require vapor sampling prior to initiating intrusive work such as contained in this 0TP. In addition, OSD-T-151-00030 requires cont inuous vapor monitoring for the duration of the intrusive work in the case of WATCHLIST TANKS AN-103, $A N-104, A N-105$, and $A N-107$. Initial vapor sample for each tank is taken from the ventilation line in the corresponding vent pit, or a Standard Hydrogen Monitoring System (SHMS) reading may be used if available. Subsequent monitoring may be performed at the location of work (i.e., at the inlet air control station).

\section{NOTE}

If the flammable gas concentration is less than or equal to $10 \%$ of the lower flammability limit (LFL), then work may continue. Also, IF the flammable gas concentration is less than or equal to $10 \%$ of the LFL, AND IF the tank is not on the flammable gas watchlist, the bonding and grounding requirements may be removed from that tank (APPLIES TO NON-WATCHLIST TANKS AN-101, AN-102, \& AN-106 ONLY).

\section{NOTE}

IF at any time the flammable gas concentration for any tank is GREATER THAN $10 \%$ of the LFL, BUT LESS THAN OR EQUAL TO 25\% (OSD-00007 \& OSD-00030):

a. STOP WORK.

b. Notify Shift 0perations, Tank Farm Transition Project Engineering, Waste Tank Process Engineering, and Nuclear Safety for evaluation in compliance with the OSD's.

c. Continue work on $1 y$ upon approval of a written plan describing how to proceed; see OSD-00007 and 0SD-00030 for current approval requirements. 


\section{NOTE}

IF at any time the flammable gas concentration is GREATER THAN $25 \%$ of the LFL (OSD-00007 \& OSD-00030):

a. STOP WORK.

b. Notify Shift Operations, Tank Farm Transition Project Engineering, Waste Tank Process Engineering, and Nuclear Safety in compliance with the Flammable Gas Control Limits and other OSD requirements.

2.3.1 If a pit entry is required to perform ventilation line vapor monitoring, open hinged ventilation pit cover in preparation for entry.

$\begin{array}{lll}\text { VENT PIT-101 } & \approx & \text { TANKS AN-102 \& AN-103 } \\ \text { VENT PIT-102 } & \approx & \text { TANKS AN-101 \& AN-104 } \\ \text { VENT PIT-103 } & \approx & \text { TANKS AN-105 \& AN-106 } \\ \text { VENT PIT-104 } & \approx & \text { TANK AN-107 }\end{array}$

2.3.2 If a pit entry is required, monitor for toxic gases, flammable gases and oxygen deficiencies before pit entry. Confined Space Entry Permit shall be required for all pit entries.

2.3.3 As required by OSD-T-151-00007 or 0SD-T-151-00030, bond the inlet air control station test port plugs or caps, vapor sample tubes, and any test equipment required to support the OTP. Bond per drawing H-2-73450, Rev. 4, Sht. 3, Note 10, Assembly E; verify bonding assembly passes required one megohm (l M $\Omega$ ) resistance check after installation.

2.3.4 Monitor vapor (i.e., sample from the ventilation line located in the ventilation pit or use an available SHMS reading, corresponding to the tank being tested) for baseline reading for flammable gases. Continuous monitoring (i.e., at $\leq 15$-minute intervals) is required for AN-103, AN-104, AN-105, and AN-107 (WATCHLIST TANKS). Record flammable gas concentrations.

2.3.5 Remove required test port cover plugs and wait 5 minutes before performing the next step.

2.3.6 Monitor vapor at the inlet air control station, or use a reading from the ventilation pit or SHMS if available, corresponding to the tank being tested, after obtaining a baseline reading for flammable gases. Continuous monitoring (i.e., at $\leq 15$ minute intervals) is required for $\mathrm{AN}-103, \mathrm{AN}-104, \mathrm{AN}-105$, or $\mathrm{AN}-107$ (WATCHLIST TANKS). Record flammable gas concentration. 


\subsection{AEROSOL PENETRATION TEST}

\section{NOTE}

Visual inspection identifies potential ventilation system problems or conditions which may affect test activities. No pass/fail inspection criteria are used. The following list may be used as a guide for items to be inspected for adequacy, deficiency, or other concerns:

- Filter housing access - Damage to filter housing or ductwork

- Damage to instrumentation - Damage to housing door or seal

- Test port access Labels on test ports

- Labels on pressure gauges - Current calibration labels

- Light level in work area - General housekeeping \& tripping hazards

2.4.1 Perform visual inspection of equipment and work area, and perform aerosol penetration test per procedure 6-TF-156 (including Appendix TV thereof).

\subsection{RESTORATION}

2.5.1 Verify aerosol test equipment has been removed and test port plugs or caps are restored.

2.5.2 If directed by the Test Director, perform flow adjustments (ref. T0-060-101). If any orifice plates have been changed, record final installed ID size and corresponding nominal flow rate; ref. drawing $\mathrm{H}-2-85647$.

2.5.3 If no more tests are to be immediately performed, but there are still remaining filters to be tested, then close and perform lock and tag on valves opened in Step 2.1.6 which correspond to units not yet tested.

\subsection{POST TESTING}

2.6.1 Test Director to review data sheets for completeness and legibility.

2.6.2 Quality Assurance (QA) to review Data Sheets for completeness and legibility. This can be done after completion of all testing.

2.6.3 Subsequent operational tests will start at Step 2.1.6, with a new set of test data sheets.

2.6.4 Survey all equipment before removal from work area, as required.

\subsection{BIBLIOGRAPHY}

ACGIH, Industrial Ventilation, Section 9, "Testing of Ventilation Systems." 
HNF-SD-WM-0TR-215 Rev. 0

ASME N510-1989, Testing of Nuclear Air Treatment Systems.

Drawing H-2-71991, Piping Plan Tank 101.

Drawing H-2-71992, Piping Plan Tank 102.

Drawing H-2-71993, Piping Plan Tank 103.

Drawing $\mathrm{H}-2-71994$, Piping Plan Tank 104.

Drawing H-2-71995, Piping Plan Tank 105.

Drawing H-2-71996, Piping Plan Tank 106.

Drawing H-2-72039, Piping P7an Tank 107.

Drawing H-2-73450, Piping Isolation Details Pipe \& Riser Closures.

Drawing H-2-85646, Air Control Station.

Drawing H-2-85647, Airflow Controller.

Drawing H-14-020101, Ventilation Tank Primary System (VTP) 0 \& $M$ System P\&ID.

ERDA 76-21, Nuclear Air Cleaning Handbook.

OSD-T-151-00007, Operating Specifications for the 241-AN, AP, AW, AY, $A Z$, and SY Tank Farms.

OSD-T-151-00030, Operating Specifications Watch List Tanks.

Procedure 7-GN-056, Airflow Capacity and Distribution Tests.

Procedure T0-060-101, Operate 241-AN Primary and Annulus Vent Systems.

Procedure 6-TF-156, HEPA Filter In-Place Leak Test (Aerosol Test), including Appendix TV, 241-AN Tank Inlet Filter Aerosol Test Data Sheets.

WHC-CM-1-10, Safety Manua7, Standard WKS-6, "Pre-Job Safety Planning," Standard WKS-21, "Ladders," Standard WKS-8.1, "Operations Lock and Tag Program," Standard WKS-22, "Scaffolding," Standard WKS-10, "Personal Protection," and Standard WKS-12, "Hand and Portable Power Tools."

WHC-CM-6-1, Standard Engineering Practices, EP-4.2, "Testing Requirements."

WHC-CM-7-5, Environmental Compliance Manual, Section 2.5.5.2, "Testing and Performance Criteria."

WHC-SD-WM-ATP-177, Acceptance Test Procedure, Air Inlet Filter and Control Station Pressure Decay Test.

WHC-SD-WM-HSP-002, Tank Farm Health and Safety Plan (HASP). 


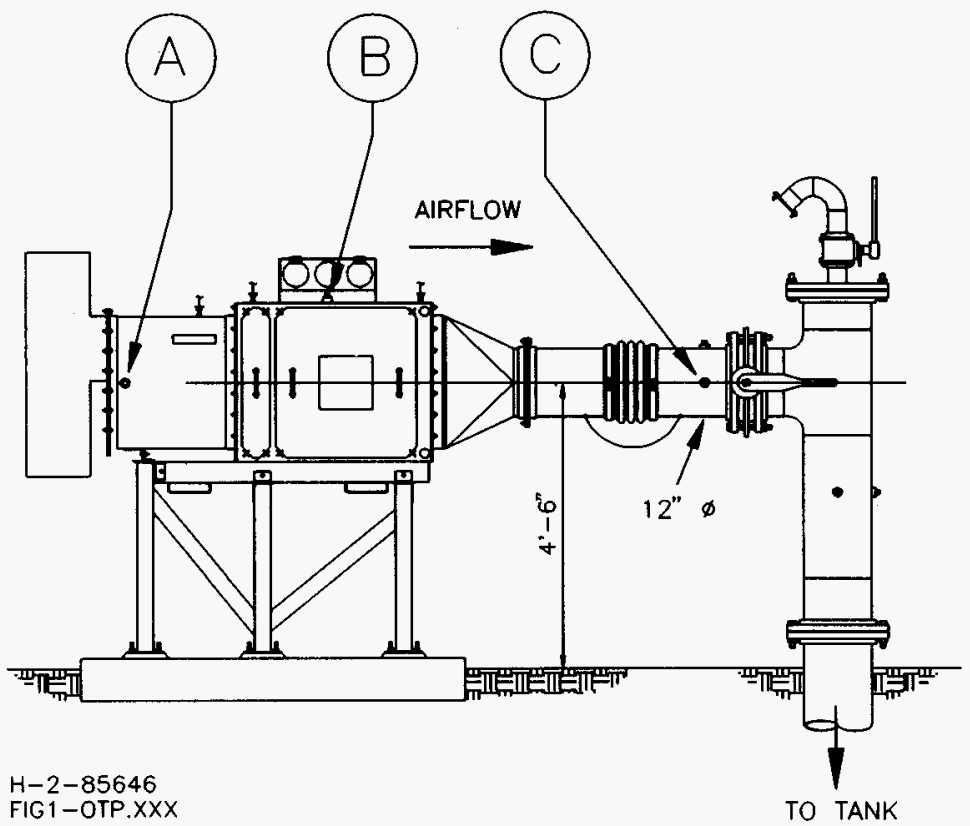

\begin{tabular}{|c|c|c|}
\hline \multirow{2}{*}{ TEST } & PORT & $\begin{array}{r}\text { HEPA FILTER VTP-FLT } \\
101 \mathrm{~B} \text { THRU 107B }\end{array}$ \\
\hline \multirow{2}{*}{ BASELINE } & INJECT & $\mathrm{A}$ \\
\cline { 2 - 3 } & SAMPLE & $\mathrm{B}$ \\
\hline \multirow{2}{*}{ PENETRATION } & INJECT & $\mathrm{A}$ \\
\cline { 2 - 3 } & SAMPLE & $\mathrm{C}$ \\
\hline
\end{tabular}

FIGURE 1. INLET FILTER TEST PORTS (TYPICAL). 
HNF-SD-WM-OTR-215 Rev. 0

TEST PARTICIPANTS IDENTIFICATION LIST

\begin{tabular}{|c|c|c|}
\hline INITIALS & PRINTED NAME & RESPONSIBILITY \\
\hline & & \\
\hline & & \\
\hline & & \\
\hline & & \\
\hline & & \\
\hline & & \\
\hline & & \\
\hline & & \\
\hline & & \\
\hline & & \\
\hline & & \\
\hline & & \\
\hline & & \\
\hline & & \\
\hline & & \\
\hline & & \\
\hline & & \\
\hline & & \\
\hline & & \\
\hline
\end{tabular}

A- 14 
TANK NUMBER: 241-AN-

TEST EXECUTION DATA SHEET

\begin{tabular}{|c|c|c|}
\hline $\begin{array}{l}\text { REFERENCE } \\
\text { STEP }\end{array}$ & $\begin{array}{l}\text { ACCEPT/REJECT* } \\
\text { (TEST DIRECTOR OR } \\
\text { DESIGNEE TO INITIAL } \\
\text { AND DATE) }\end{array}$ & RECORDED VALUES (INCLUDE UNITS), OBSERVATIONS, OTHER DATA \\
\hline $\begin{array}{l}2.1 .1- \\
2.1 .4\end{array}$ & & \\
\hline $\begin{array}{c}2.1 .5- \\
2.1 .8\end{array}$ & & \\
\hline $\begin{array}{c}2.2 .1- \\
2.2 .5\end{array}$ & & \\
\hline $\begin{array}{c}2.3 .1 \& \\
2.3 .2^{\&}\end{array}$ & & \\
\hline 2.3 .3 & & \\
\hline 2.3 .4 & & $\begin{array}{l}\text { ELECTRICAL RESISTANCE IN } \Omega: \\
\text { CALI BRATION DUE DATE: } \\
\text { LESS THAN ONE MEGOHM ( } 1 \mathrm{M} \Omega) ?:\end{array}$ \\
\hline
\end{tabular}




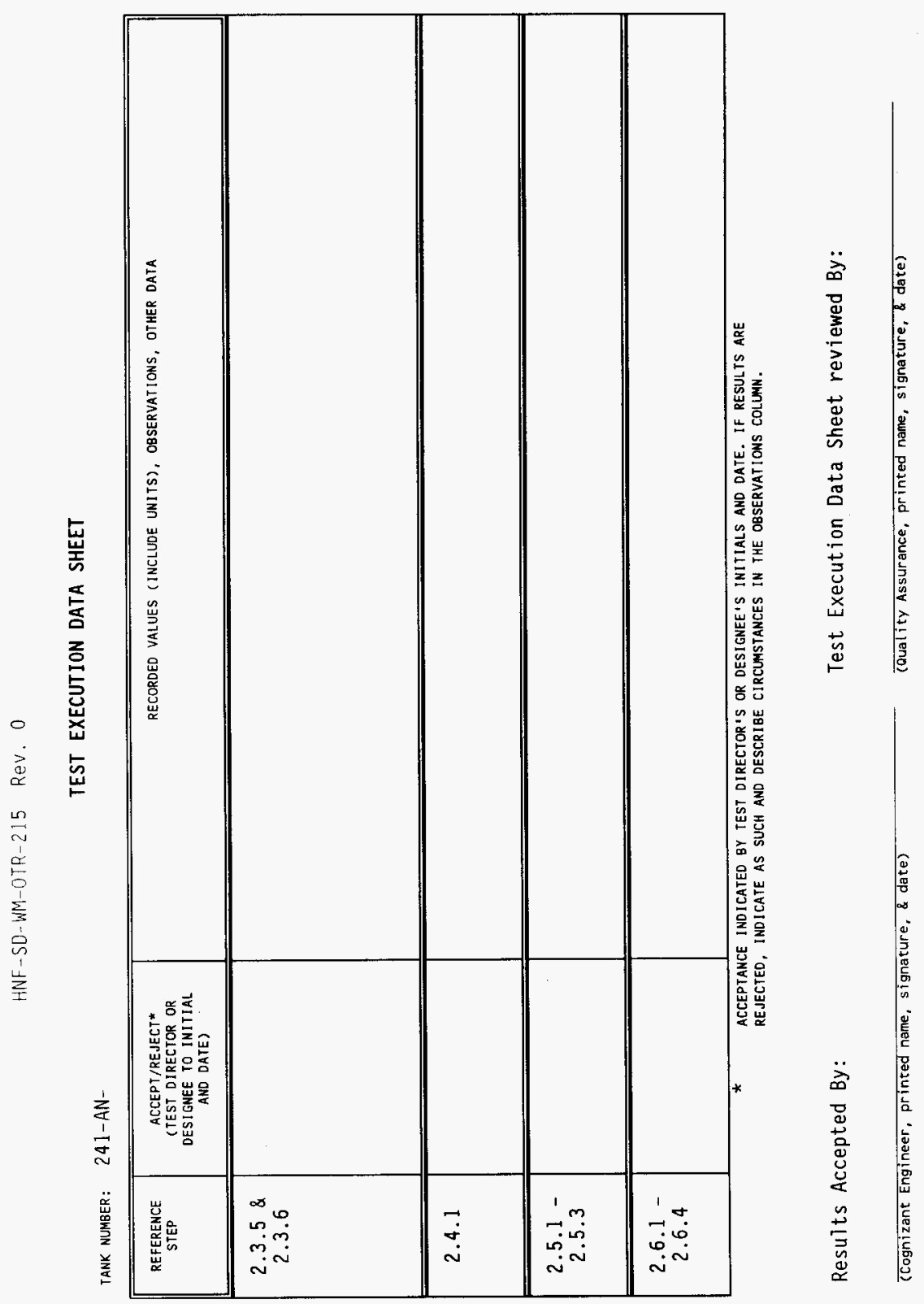




\section{HNF-SD-WM-OTR-215 Rev. 0 \\ RECORD OF TEST EXCEPTION}

TANK NUMBER: 241-AN-

TEST EXCEPTION NUMBER:

\section{EXCEPTION}

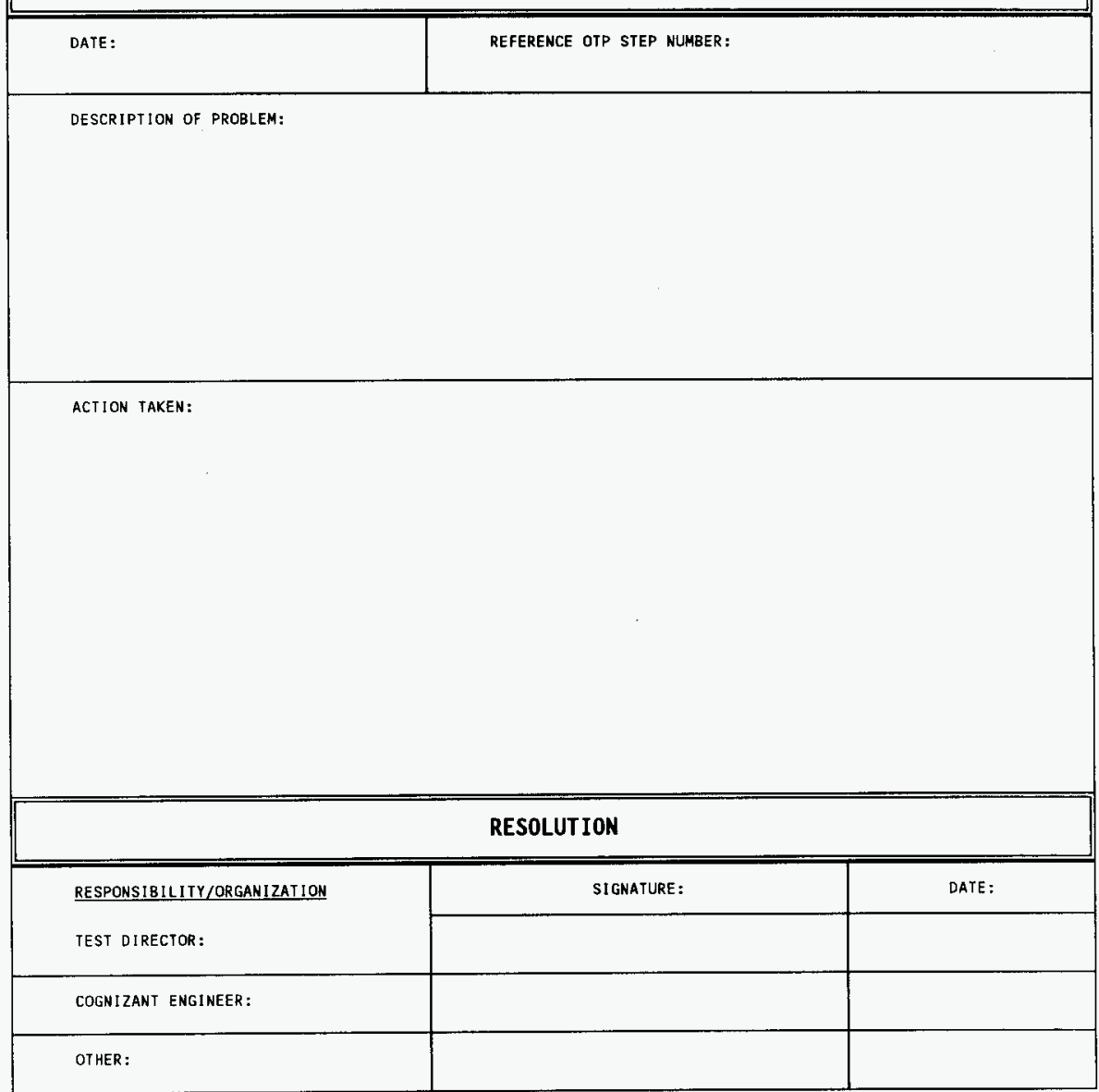

Record of Test Exception reviewed By:

(Quality Assurance, printed name, signature, \& date)

[MAKE ADDITIONAL COPIES AS REQUIRED; ONE EXCEPTION PER SHEET] 
HNF-SD-WM-0TR-215 Rev. 0

APPENDIX B: TEST DATA SHEETS AND PARTICIPANTS LIST

B-1 


\begin{tabular}{|c|c|c|}
\hline \multicolumn{3}{|c|}{ HE-SQ IT $2(11 / 98$} \\
\hline $\begin{array}{l}\text { REFEREACE } \\
\text { STEP }\end{array}$ & $\begin{array}{l}\text { ACCEPT/RESEC广* } \\
\text { (TEST D/RECTOR OR } \\
\text { DESIGEE TO INITIAL } \\
\text { AND DATE) }\end{array}$ & RECORDED VALUES (INCLUDE UNITS), OBSERVATIONS, OTHER DATA \\
\hline $\begin{array}{l}2.1 .1- \\
2.1 .4\end{array}$ & $\begin{array}{l}D J M \\
1-28-97\end{array}$ & $\begin{array}{l}\text { Note: dPgages have been calibrated (1.5.5) and pressure decay test has been } \\
\text { completed (1.5.6), } \\
\text { Vent pit cover open pit monitoring complete-measured gas and } 0_{2} \text { levels } \\
\text { are aceeptable, Vent values)open, Tank vacuum, AN-101-107(IN WG): } \\
1.5,1.8,1.6,1.8,2.0,1.7,2.2\end{array}$ \\
\hline $\begin{array}{l}2.1 .5- \\
2.1 .8\end{array}$ & $\begin{array}{l}D J M \\
1-28-97\end{array}$ & $\begin{array}{l}\text { Lock and tag removed, } \\
\text { station isolation value open, } \\
\text { N/A for } 2.1 .7 \text { and } 2.1 .8 \text { (other stations will be brought on-line as tested) }\end{array}$ \\
\hline $\begin{array}{l}2.2 .1- \\
2.2 .5\end{array}$ & $\begin{array}{l}D J M \\
1-28-97\end{array}$ & $\begin{array}{l}\text { 125 sefm arifice plate installed per wHC-sD-wM-ATR-178 (verified } \\
\text { again if changed out perstep } 2.5 .2 \text { ), } \\
\text { Port controller is levitated, and drops and raises freely, } \\
\text { Fow controller PASSES simple/final functional test }\end{array}$ \\
\hline $\begin{array}{l}2.3 .1 \& \\
2.3 .2\end{array}$ & $\begin{array}{l}D J M \\
1-28-97\end{array}$ & $\begin{array}{l}\text { pit entry for monitoring } \\
\text { is not repoired }\end{array}$ \\
\hline 2.3 .3 & $\begin{array}{l}D J M \\
1-28-97\end{array}$ & $\begin{array}{l}\text { Bonding of applicable plugs/instruments complete, } \\
\text { Resistance check verified LIM }<\end{array}$ \\
\hline 2.3 .4 & $\begin{array}{l}D I M \\
1-28-97\end{array}$ & $\begin{array}{l}N / A \\
\text { Flammable gas c-ncentration: } 0 \% \text { LEL } \\
\text { Location: Dome }\end{array}$ \\
\hline
\end{tabular}


TANK NUMBER: 241-AN-10!

\section{TEST EXECUTION DATA SHEET}

\begin{tabular}{|c|c|c|}
\hline $\begin{array}{l}\text { REFERENCE } \\
\text { STEP }\end{array}$ & $\begin{array}{l}\text { ACCEPT/REJECT } \\
\text { (TEST DIRECTOR OR } \\
\text { DESIGMEE TO INITIAL } \\
\text { AND DATE) }\end{array}$ & RECORDEO VALUES (INCLUDE UNITS), OBSERVATIONS, OTHER DATA \\
\hline $\begin{array}{c}2.3 .5 \& \\
2.3 .6\end{array}$ & $\begin{array}{l}D J M \\
1-28-97\end{array}$ & $\begin{array}{l}\text { Plugs removed for } 5 \text { minutes, } \\
\text { Flammable gas concentration: } 0 \% \text { LEL } \\
\text { Location: Dome }\end{array}$ \\
\hline 2.4 .1 & $\begin{array}{l}D J M \\
1-28-97\end{array}$ & $\begin{array}{l}\text { Filter PASSES aerosol testing, see attached } \\
\text { vent + Balance test data sheet-s }\end{array}$ \\
\hline $\begin{array}{c}2.5 .1 \\
2.5 .3\end{array}$ & $\begin{array}{l}D J M \\
h-28-97\end{array}$ & $\begin{array}{l}\text { Eguipment restored, } \\
\text { Final installed orifice size (inches): } 2-1 / 16 \text { (60 cfm) }\end{array}$ \\
\hline $2.6 .1-$ & $\begin{array}{l}D I M \\
1-28-97\end{array}$ & $\begin{array}{l}\text { Pata sheets are emolete } \\
\text { and ready for } P \text { A review }\end{array}$ \\
\hline
\end{tabular}

ACCEPTANCE INDICATED BY IEST DIRECTOR'S OR DESIGNEE'S INITIALS AND DATE IF RESULTS ARE REJECTED, INDICATE AS SUCH AND DESCRIBE CIRCUMSTANCES IN THE OBSERVATIONS COLUMN.

Results Accepted By:

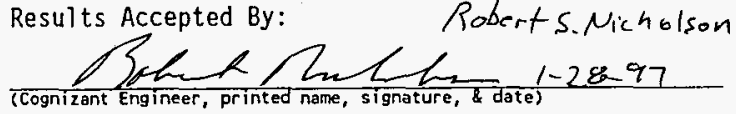

Test Execution Data Sheet reviewed By:

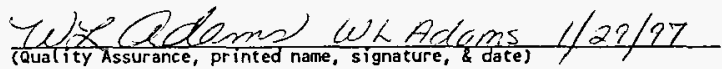


TANK NUMBER: $\quad 241-\mathrm{AN}-102$

\section{TEST EXECUTION DATA SHEET}

\begin{tabular}{|c|c|c|}
\hline $\begin{array}{l}\text { REFERENCE } \\
\text { SIEP }\end{array}$ & $\begin{array}{l}\text { ACCEPT/REJEC }{ }^{*} \\
\text { (TEST DIRECTOR OR } \\
\text { DESIGNEE TO INITIAL } \\
\text { AND DATE) }\end{array}$ & RECORDED VALUES (INCLUDE UNITS), OBSERVATIONS, OIHER DATA \\
\hline $\begin{array}{l}2.1 .1- \\
2.1 .4\end{array}$ & $\begin{array}{l}D J M \\
1-28-97\end{array}$ & 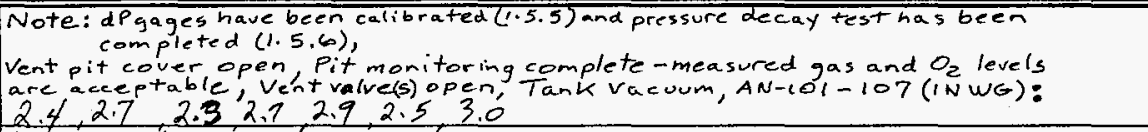 \\
\hline $2.1 .5-$ & $\begin{array}{l}D=M \\
1-28-97\end{array}$ & $\begin{array}{l}\text { Lock and tag removed, } \\
\text { station isolation value open, } \\
N / A \text { for } 2.1 .7 \text { and } 2.1 .8 \text { (other stations will be brought on-line as fested) }\end{array}$ \\
\hline $\begin{array}{l}2.2 .1- \\
2.2 .5\end{array}$ & $\begin{array}{l}05 M \\
1-28-77\end{array}$ & $\begin{array}{l}125 \text { scfm orifice plate imstalled per whe-sD-WM-ATR-178 (verified } \\
\text { again if changed out per step } 2.5 .2 \text { ), } \\
\text { port controller is levitated, and drops and raises freely, } \\
\text { Fow controller PASSES simple/final functional test }\end{array}$ \\
\hline $\begin{array}{l}2.3 .1 \& \\
2.3 .2\end{array}$ & $\begin{array}{l}D J M \\
1-28-97\end{array}$ & $\begin{array}{l}\text { pit entry for monitoring } \\
\text { is not reg oired }\end{array}$ \\
\hline 2.3 .3 & $\begin{array}{l}D J M \\
1-28-97\end{array}$ & $\begin{array}{l}\text { Bonding of applicable plugs/instruments complete, } \\
\text { Resistame check verified }<1 M \Omega\end{array}$ \\
\hline 2.3 .4 & $\begin{array}{l}D=M \\
1-28-97\end{array}$ & 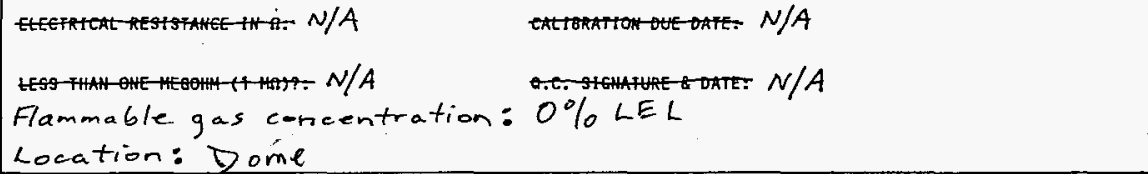 \\
\hline
\end{tabular}




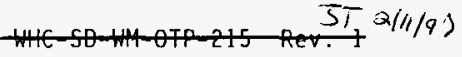

TANK RUMBER: 241-AN-102

\section{TEST EXECUTION DATA SHEET}

\begin{tabular}{|c|c|c|}
\hline $\begin{array}{l}\text { REFERENCE } \\
\text { STEP }\end{array}$ & $\begin{array}{l}\text { ACCEPT/REJECT* } \\
\text { (TEST DIRECTOR OR } \\
\text { DESIGNEE TO INITIAL } \\
\text { AND DATE) }\end{array}$ & RECORDED VALUES (INCLUDE UNITS), OGSERVATIONS, OTHER DATA \\
\hline $\begin{array}{c}2.3 .5 \& \\
2.3 .6\end{array}$ & $\begin{array}{l}D J M \\
1-28-97\end{array}$ & $\begin{array}{l}\text { Plugs removed for } 5 \text { minutes, } \\
\text { Flammable gas concentration: } 0 \% \text { LEL } \\
\text { Location: Dome }\end{array}$ \\
\hline 2.4 .1 & $\begin{array}{l}D=M \\
1-28-97\end{array}$ & $\begin{array}{l}\text { Filter PASSES aerosol testing, see attached } \\
\text { Vent + Balance test data sheets }\end{array}$ \\
\hline $2.5 .1-$ & $\begin{array}{l}D T M \\
1-28-97\end{array}$ & $\begin{array}{l}\text { Equipment restored, } \\
\text { Final installed orifice size (inches): } 2-7 / 16(60 \mathrm{cfm})\end{array}$ \\
\hline $2.6 .1-$ & $\begin{array}{l}D J M \\
1-28-97\end{array}$ & $\begin{array}{l}\text { Pata sheets are complefe } \\
\text { and ready for } Q A \text { review }\end{array}$ \\
\hline
\end{tabular}

Results Accepted By:

Robert S. Nicholson (Cognizant Engineer, printed name, signature, \& date) $1-28-97$
Test Execution Data Sheet reviewed By:

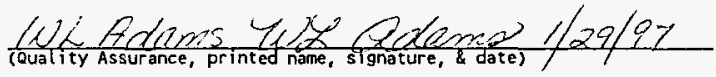




\begin{tabular}{|c|c|c|}
\hline TANK NUMBER: & $241-A N-103$ & TEST EXECUTION DATA SHEET \\
\hline $\begin{array}{c}\text { REFERENCE } \\
\text { STEP }\end{array}$ & $\begin{array}{l}\text { ACCEPT/REJECI* } \\
\text { (IEST DIRECTOR OR } \\
\text { DESIGEE TO INITIAL } \\
\text { ANO DATE) }\end{array}$ & 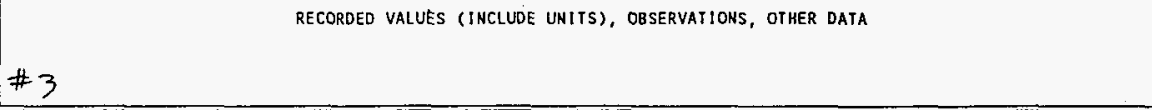 \\
\hline $\begin{array}{l}2.1 .1 \\
2.1 .4\end{array}$ & $\begin{array}{l}D J M \\
1-28-97\end{array}$ & $\begin{array}{l}\text { Note: dPgages have been calibrated (1.5.5) and pressure decay test has been } \\
\text { completed (1.5.6), } \\
\text { Vent pit cover open pit monitoring complete-measured gas and } O_{2} \text { level.s } \\
\text { are aceptable, Vent value(s) open, Tank vacuum, AN-101-107(IN WG): } \\
\text { NR } 2.0,1.8,2.0,2.3,2.0,2.5\end{array}$ \\
\hline $\begin{array}{c}2.1 .5- \\
2.1 .8\end{array}$ & $\begin{array}{l}D=M \\
1-28-97\end{array}$ & $\begin{array}{l}\text { Lock and tag removed, } \\
\text { station isolation valve open, } \\
N / A \text { for } 2.1 .7 \text { and } 2.1 .8 \text { (other stations will be brought on-line as tested) }\end{array}$ \\
\hline $\begin{array}{l}2.2 .1- \\
2.2 .5\end{array}$ & $\begin{array}{l}D J M \\
1-28-97 \\
\end{array}$ & $\begin{array}{l}125 \text { sefm arifice plate installed per whic-sD-WM-ATR-178 (verified } \\
\text { again if changed owt perstep } 2.5 .2 \text {, } \\
\text { Port controiler is levitated, and drops and raises freely, } \\
\text { Flow controller PASSES simple/final functional test }\end{array}$ \\
\hline $\begin{array}{c}2.3 .1 \& \\
2.3 .2^{\&}\end{array}$ & $\begin{array}{l}\text { DIM } \\
1-28-97\end{array}$ & $\begin{array}{l}\text { pit entry for monitoring } \\
\text { is not regoired }\end{array}$ \\
\hline 2.3 .3 & $\begin{array}{l}D J M \\
1-28-97\end{array}$ & $\begin{array}{l}\text { Bonding of applicable plugs/instruments complete, } \\
\text { Resistamee cheek verified }<1 M \Omega\end{array}$ \\
\hline 2.3 .4 & $\begin{array}{l}D J M \\
1-28-97\end{array}$ & $\begin{array}{l}N / A \\
\text { Flamable gas c-ricentration: } 0 \% \mathrm{LEL} \\
\text { Location: Dome }\end{array}$ \\
\hline
\end{tabular}




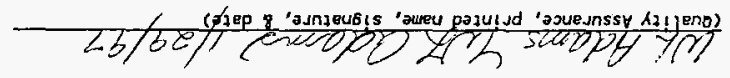

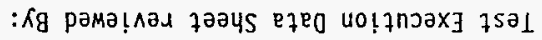

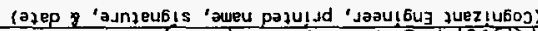

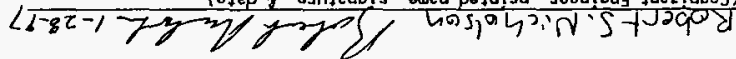
: א8 pazdaวjy szlnsay

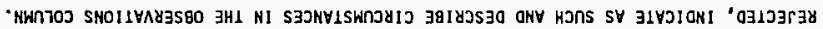

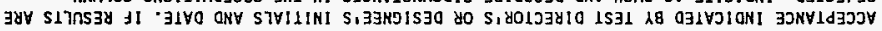

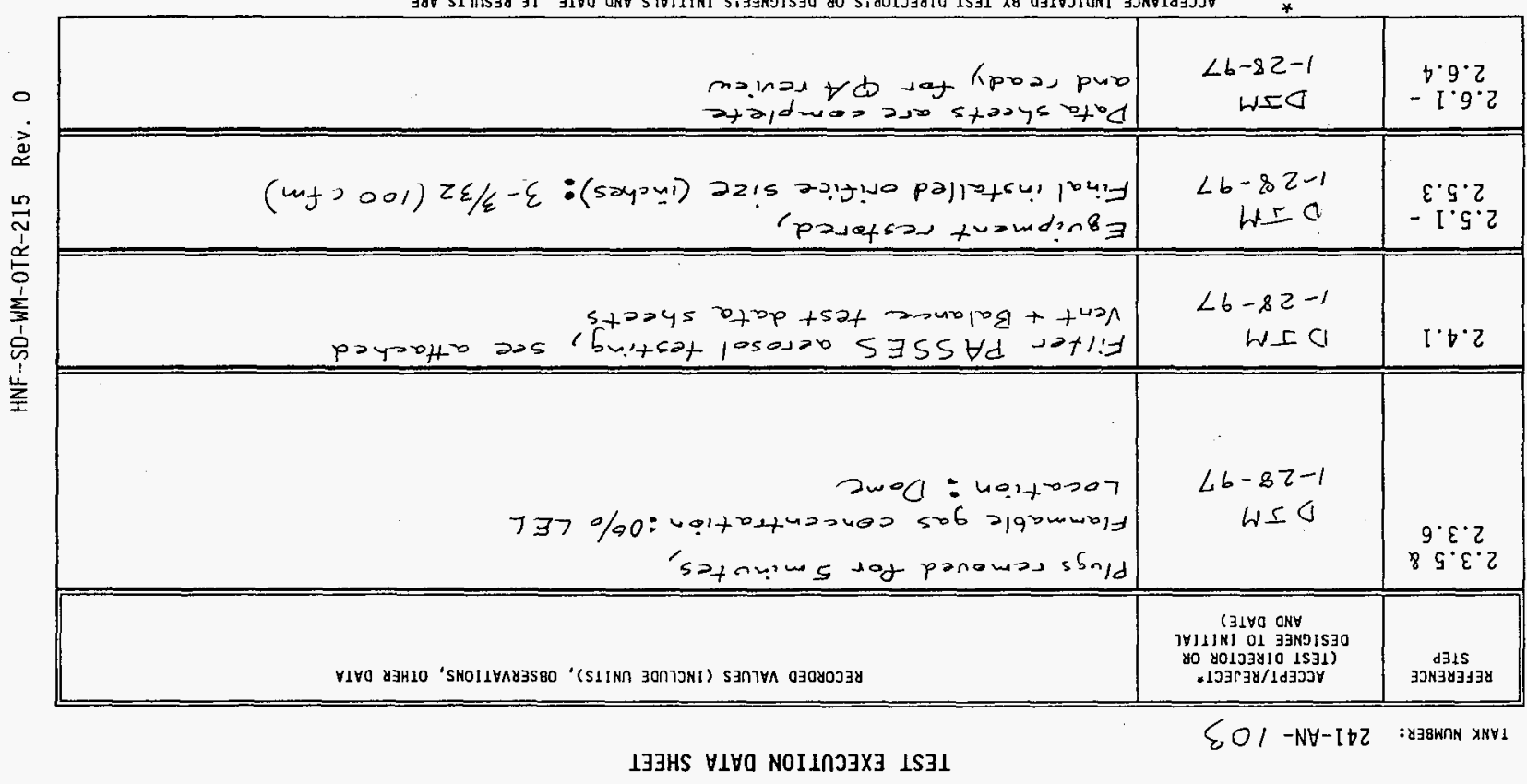




\begin{tabular}{|c|c|c|}
\hline \multicolumn{3}{|r|}{ TEST EXECUTION DATA SHEET } \\
\hline $\begin{array}{c}\text { REFERENCE } \\
\text { STEP }\end{array}$ & $\begin{array}{l}\text { ACCEPT/REJECY* } \\
\text { (IEST DIRECTOR OR } \\
\text { DESIGEE TO INITIAL } \\
\text { AND DATE) }\end{array}$ & RECORDEO VALUES (INCLUDE UNITS), OBSERVATIONS, OTHER DATA \\
\hline$\frac{2.1 .1-}{2.1 .4}$ & $\begin{array}{l}D J M \\
1-28-97 \\
\end{array}$ & 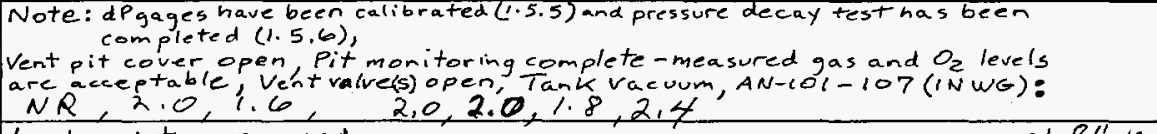 \\
\hline $\begin{array}{l}2.1 .5- \\
2.1 .8\end{array}$ & $\begin{array}{l}D J M \\
1-28-97\end{array}$ & $\begin{array}{l}\text { Lock and tag removed, } \\
\text { station isolation value open, } \\
\mathrm{N} / \mathrm{A} \text { for } 2.1 .7 \text { and } 2.1 .8 \text { (other stations will be brought on-line as tested) }\end{array}$ \\
\hline $\begin{array}{l}2.2 .1- \\
2.2 .5\end{array}$ & $\begin{array}{l}0 J M \\
1-28-97\end{array}$ & $\begin{array}{l}125 \text { sefm arifice plate installed per wHe-SD-WM-ATR-178 (verified } \\
\text { again if changed out per step } 2.5,2 \text { ), } \\
\text { Port contooller is levitated, and drops and raises freely, } \\
\text { Flow controller PASSES simple/final functional test } \\
\end{array}$ \\
\hline $\begin{array}{l}2.3 .1 \& \\
2.3 .2\end{array}$ & $\begin{array}{l}15 T \\
1-28-97\end{array}$ & $\begin{array}{l}\text { Pit entry for monitoring } \\
\text { is not regoired }\end{array}$ \\
\hline 2.3 .3 & $\begin{array}{l}D J M \\
1-28-97\end{array}$ & $\begin{array}{l}\text { Bonding of applicable plugs/instruments complete, } \\
\text { Resistamee cheek verified }<1 M \Omega\end{array}$ \\
\hline 2.3 .4 & $\begin{array}{l}D J M \\
1-28-97\end{array}$ & $\begin{array}{l}N / A \\
\text { Flammable gas concentration: } 0 \% \mathrm{LEL} \\
\text { Location: } \mathrm{N} \text { : } \mathrm{N} / \mathrm{A} \\
\end{array}$ \\
\hline
\end{tabular}




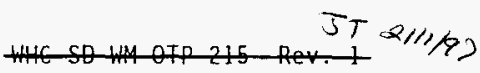

TANX NUMBER: $241-\mathrm{AN}-104$

TEST EXECUTION DATA SHEET

\begin{tabular}{|c|c|c|}
\hline $\begin{array}{l}\text { REFERENCE } \\
\text { STEP }\end{array}$ & $\begin{array}{l}\text { ACCEPT/REJECT } \\
\text { (TEST DIRECTOR OR } \\
\text { DESIGNEE TO INITIAL } \\
\text { AND DATE) }\end{array}$ & RECORDED VALUES (INCLUDE UNITS), OBSERVATIONS, OTHER DATA \\
\hline $\begin{array}{c}2.3 .5 \text { \& } \\
2.3 .6\end{array}$ & $\begin{array}{l}D J M \\
1-28-97\end{array}$ & $\begin{array}{l}\text { Plugs removed for } 5 \text { minutes, } \\
\text { Flammable gas concentiation: } 0 \%<\angle E< \\
\text { Location: Dome. }\end{array}$ \\
\hline 2.4 .1 & $\begin{array}{l}D J M \\
1-28-97\end{array}$ & $\begin{array}{l}\text { Filter PASSES aerosol testing, see attached } \\
\text { vent + Balance test data sheet's }\end{array}$ \\
\hline $\begin{array}{c}2.5 .1- \\
2.5 .3\end{array}$ & $\begin{array}{l}D M \\
1-28-97\end{array}$ & $\begin{array}{l}\text { Equipment restored, } \\
\text { Final installed orifice size (inches): } 3-3 / 32 \text { (100 cfm) }\end{array}$ \\
\hline $\begin{array}{c}2.6 .1 \\
2.6 .4\end{array}$ & $\begin{array}{l}D J M \\
-28-97\end{array}$ & $\begin{array}{l}\text { Pata sheets are complete } \\
\text { and ready for } 9 \text { A revieu }\end{array}$ \\
\hline
\end{tabular}

Results Accepted By:

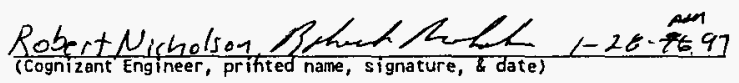

Test Execution Data Sheet reviewed By:

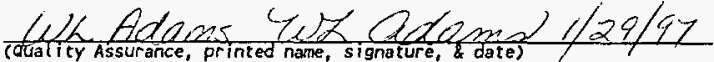




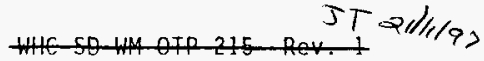

TAMK NUMBER: $241-$ AN- 105

\section{TEST EXECUTION DATA SHEET}

\begin{tabular}{|c|c|c|}
\hline $\begin{array}{l}\text { REFERENCE } \\
\text { STEP }\end{array}$ & $\begin{array}{l}\text { ACCEPT/REJECT* } \\
\text { (TEST DIRECTOR OR } \\
\text { DESIGNEE TO IITIALL } \\
\text { AND DATE) }\end{array}$ & RECORDED VALUES (INCLUDE UNITS), OBSERVATIONS, OTHER DATA \\
\hline $\begin{array}{l}2.1 .1- \\
2.1 .4\end{array}$ & $\begin{array}{l}D J M \\
1-28-97\end{array}$ & $\begin{array}{l}\text { Note: dPgages have been calibrated (1.5.5) and pressure decay test has been } \\
\text { completed }(1.5 .6) \text {, } \\
\text { vent pit cover open, Pit monitoring complete-measured,gas and } O_{2} \text { levels } \\
\text { are aceetable, Veht valve(s)open, Tank vacuum, AN-101-107(IN WG): } \\
2.0,2.2,2.0,2.3,2.4,2.1,2.5\end{array}$ \\
\hline $\begin{array}{l}2.1 .5- \\
2.1 .8\end{array}$ & $\begin{array}{l}D J M \\
1-28-97\end{array}$ & $\begin{array}{l}\text { Lock and tag removed, } \\
\text { station isolation value open. } \\
\mathrm{N} / \mathrm{A} \text { for } 2.1 .7 \text { and } 2.1 .8 \text { (other stations will be brought ondine as tested) }\end{array}$ \\
\hline $\begin{array}{c}2.2 .1- \\
2.2 .5\end{array}$ & $\begin{array}{l}D J M \\
1-28-97\end{array}$ & $\begin{array}{l}125 \text { scfm srifice plate imstalled per wHe-SD-WM-ATR-178 (verified } \\
\text { again if ehanged out per step } 2.5 .2 \text {, } \\
\text { Portcontroller is levitated, and drops and raises freely, } \\
\text { Flow controller PASSES simple/final functional test }\end{array}$ \\
\hline $\begin{array}{c}2.3 .1 \& \\
2.3 .2^{\&}\end{array}$ & $\begin{array}{l}D J M \\
1-28-97\end{array}$ & $\begin{array}{l}\text { pit entry for manitoring } \\
\text { is not reg ired }\end{array}$ \\
\hline 2.3 .3 & $\begin{array}{l}D J M \\
1-28-97\end{array}$ & $\begin{array}{l}\text { Bonding of applicable plugs/instroments complete, } \\
\text { Resistane cheek werified }<\mid M \Omega\end{array}$ \\
\hline 2.3 .4 & $\begin{array}{l}D J M \\
1-28-97\end{array}$ & $\begin{array}{l}\text { Flammable gas e-ncentration: } 0 \% \text { LEL } \\
\text { Location: Dome }\end{array}$ \\
\hline
\end{tabular}




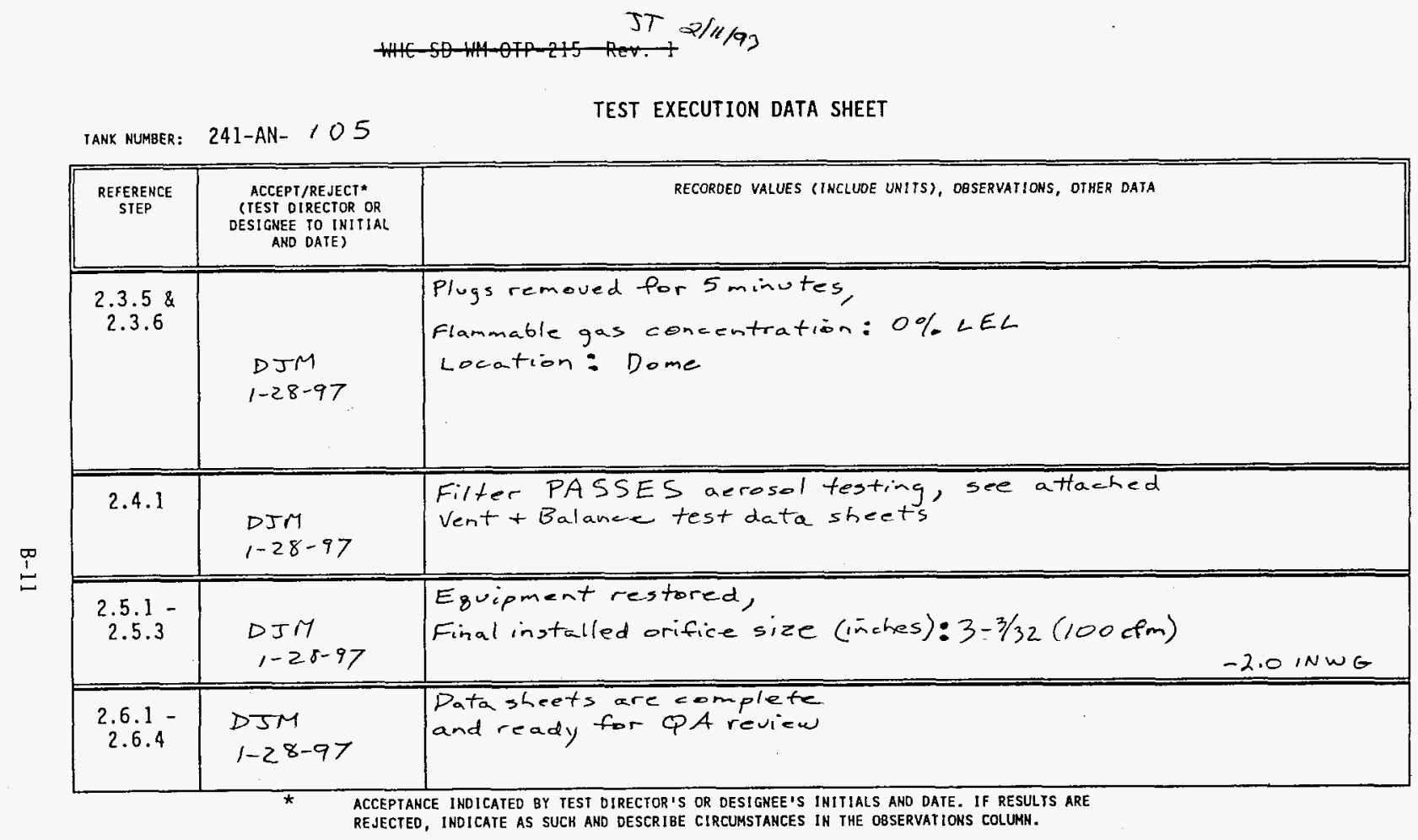

Results Accepted By:

\section{RobertNicholson Rubahec 1-28-87}

(Cognizant Engíneer, printed name, signature, $\&$ date)
Test Execution Data Sheet reviewed By:

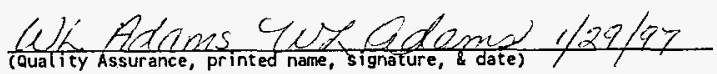




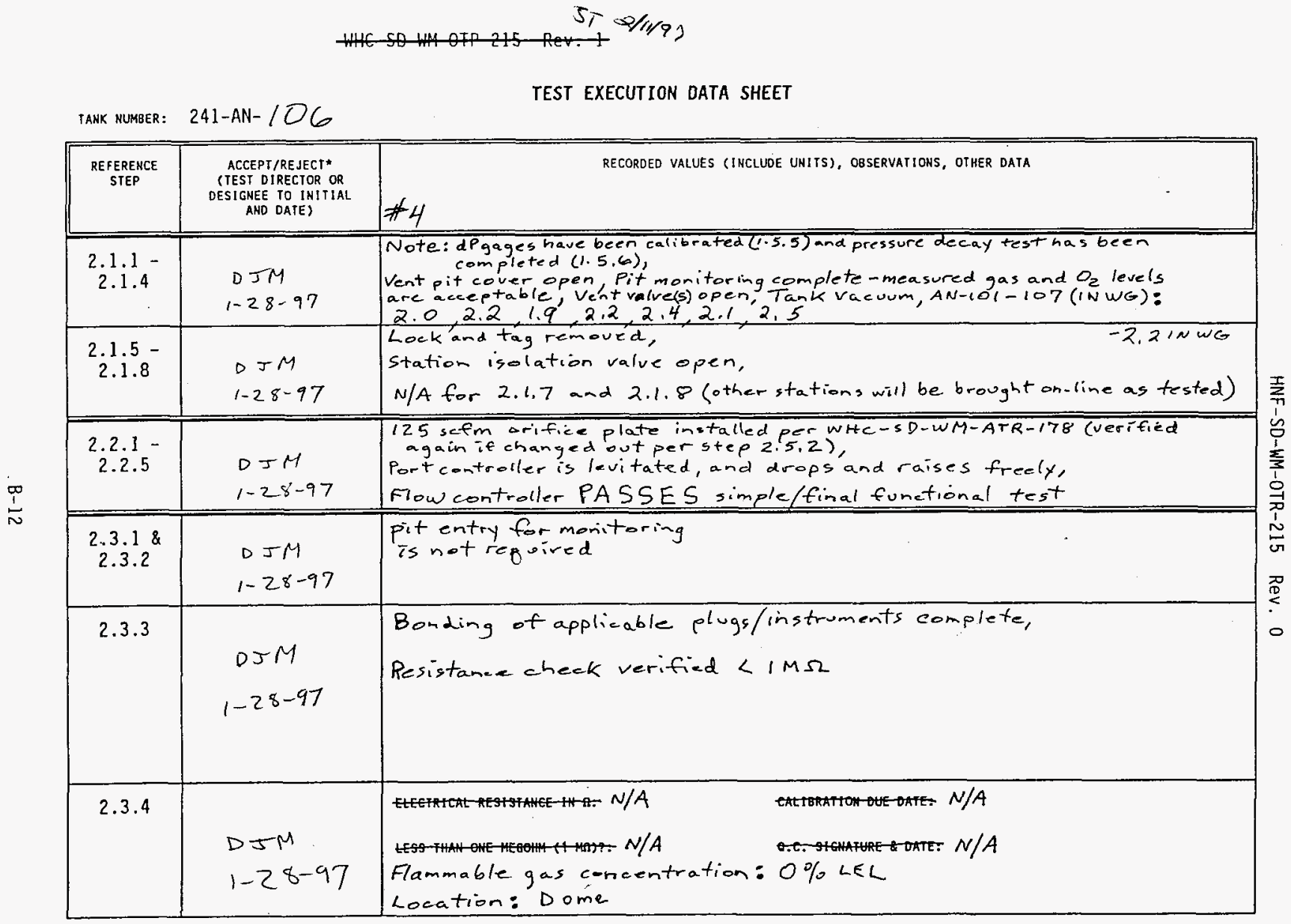




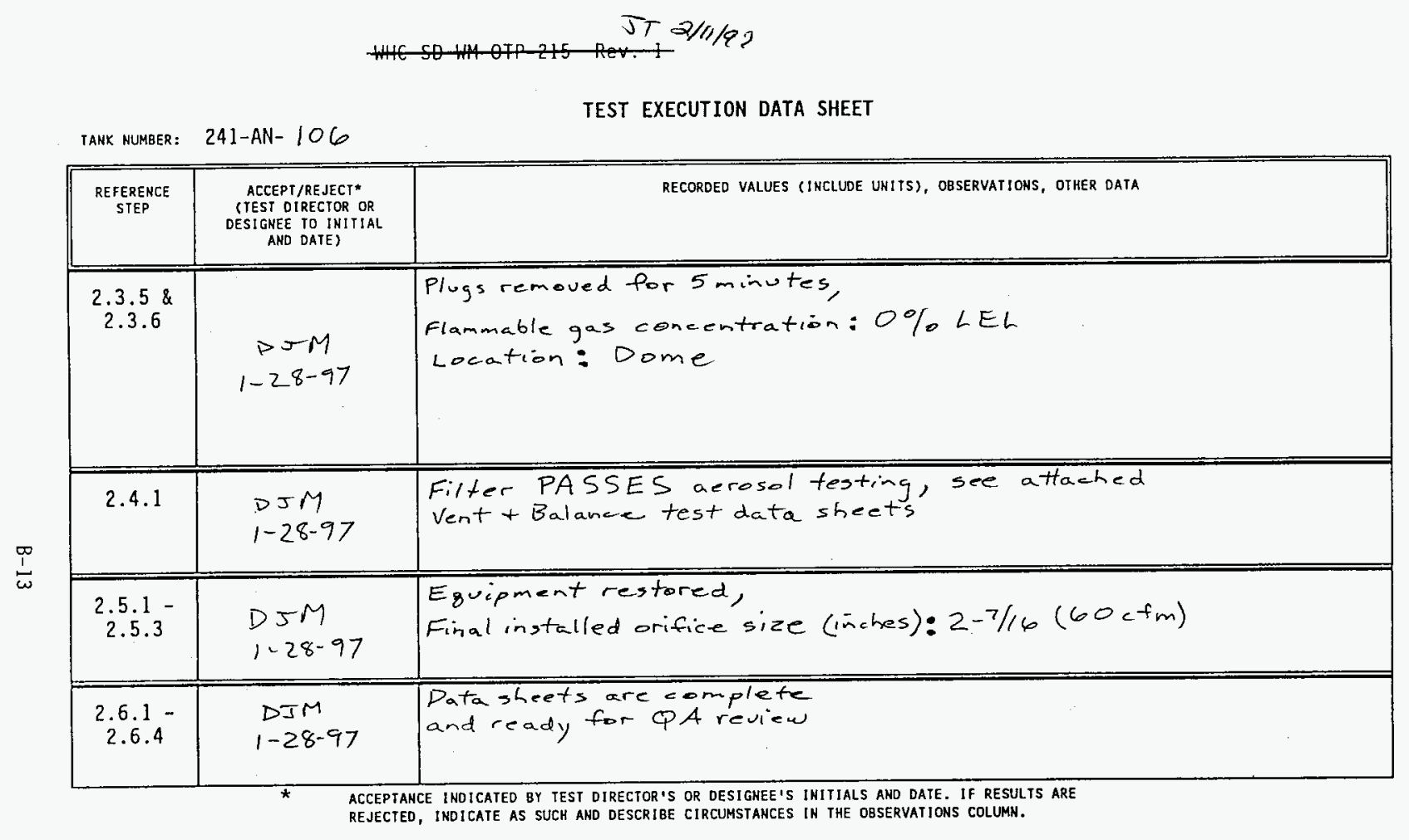

Results Accepted By: Robest Nichols on bhach hew 1-28.27 Test Execution Data Sheet reviewed By:

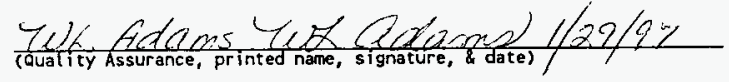




\begin{tabular}{|c|c|c|}
\hline TANK NUMBER: & $241-\mathrm{AN}-107$ & TEST EXECUTION DATA SHEET \\
\hline $\begin{array}{l}\text { REFERENCE } \\
\text { STEP }\end{array}$ & $\begin{array}{l}\text { ACCEPT/REJECT* } \\
\text { (TEST DIRECTOR OR } \\
\text { DESIGEE TO INITIAL } \\
\text { AND DATES }\end{array}$ & 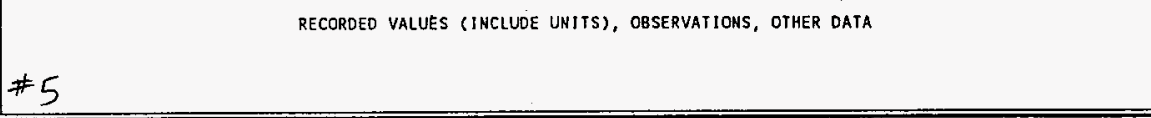 \\
\hline $\begin{array}{l}2.1 .1- \\
2.1 .4\end{array}$ & $\begin{array}{l}\text { DJM } \\
1-25-97\end{array}$ & $\begin{array}{l}\text { Note: dPgages have been calibrated (1.5.5) and pressure decay test has been } \\
\text { completed (1.5.6), } \\
\text { Vent pit cover open Pit monitoring complete-measured gas and } O_{2} \text { levels } \\
\text { are acce table, Ventvalve(s)open, Tank vacuum, AN-101-107(1N WG): } \\
1.9,2.7,2.0,2.1,2.2,2.0,2.5\end{array}$ \\
\hline $\begin{array}{l}2.1 .5- \\
2.1 .8\end{array}$ & $\begin{array}{l}D J M \\
1-28-97\end{array}$ & $\begin{array}{l}\text { Lock and tag remoued, } \\
\text { Station isolation value open, } \\
N / A \text { for } 2.1 .7 \text { and } 2.1 .8 \text { (other stations will be brought ondine as tested) }\end{array}$ \\
\hline $\begin{array}{c}2.2 .1- \\
2.2 .5\end{array}$ & $\begin{array}{l}D J M \\
1-28-97\end{array}$ & $\begin{array}{l}125 \text { sefm arifice plate installed perwite-sD-WM-ATR-178 (verified } \\
\text { again if changed out per step } 2.5,2 \text { ), } \\
\text { Port controller is levitated, and drops and raises freely, } \\
\text { Flow controller PASSES simple/final functional test }\end{array}$ \\
\hline $\begin{array}{c}2.3 .1 \& \\
2.3 .2\end{array}$ & $\begin{array}{l}D J M \\
1-28-97\end{array}$ & $\begin{array}{l}\text { pit entry formonitaring } \\
\text { is regoired, pit cover open, monitaing complete, } \\
\text { meagured gas } t \text { 'oz levels aceptable }\end{array}$ \\
\hline 2.3 .3 & $\begin{array}{l}D J M \\
1-28-97\end{array}$ & $\begin{array}{l}\text { Bonding of applicable plugs/instruments complete, } \\
\text { Resistanee cheak verified }<\mid M \Omega\end{array}$ \\
\hline 2.3 .4 & $\begin{array}{l}D 5 M \\
1-28-97\end{array}$ & $\begin{array}{l}\text { N/A } \\
\text { Flamable gas e-ncentration: } 0 \% \text { LEL } \\
\text { Location: Vent pit }\end{array}$ \\
\hline
\end{tabular}


TANK NUMBER: 241-AN-107

TEST EXECUTION DATA SHEET

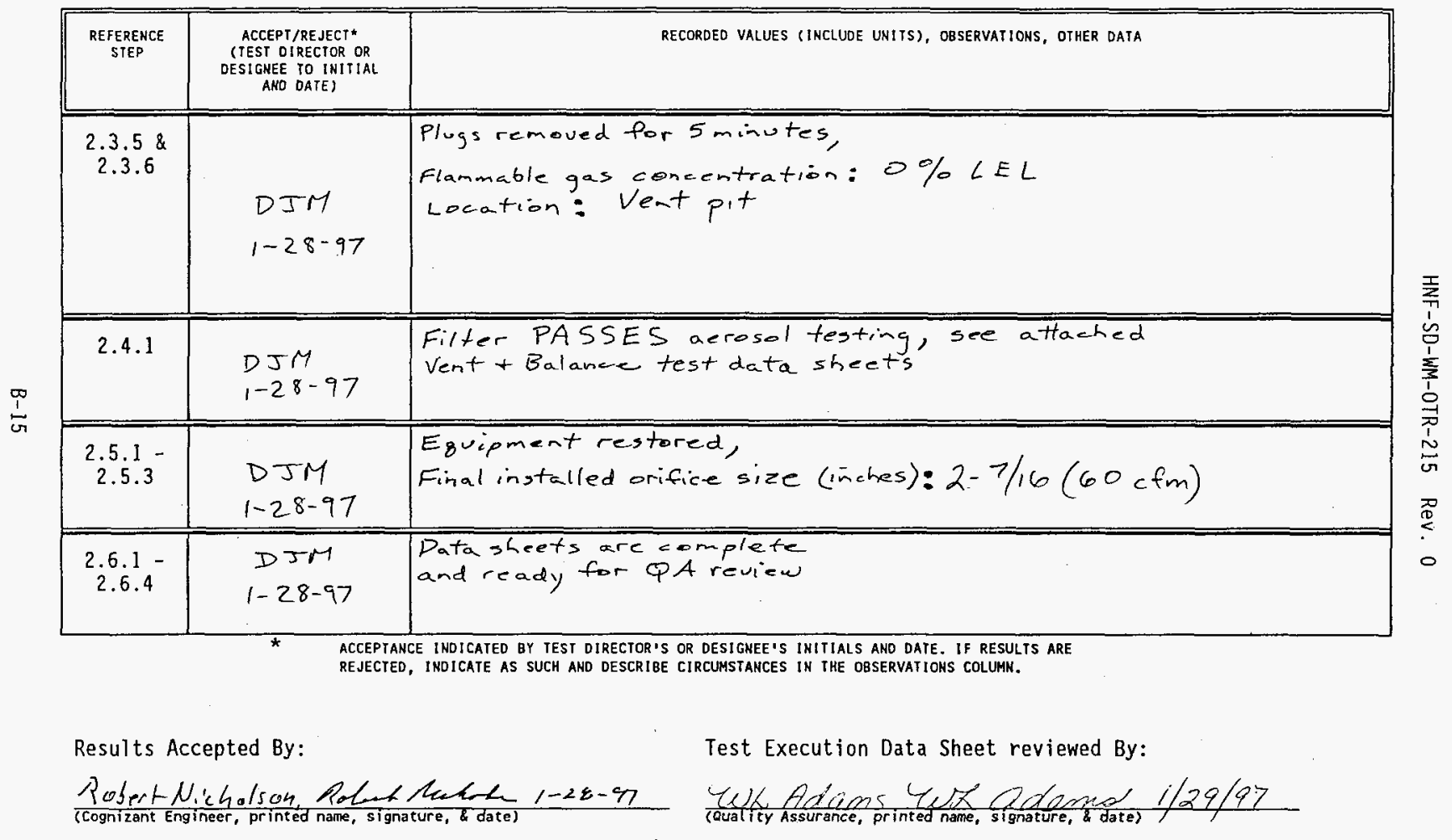




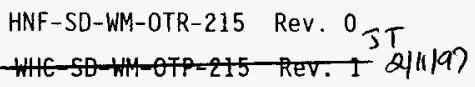

TEST PARTICIPANTS IDENTIFICATION LIST

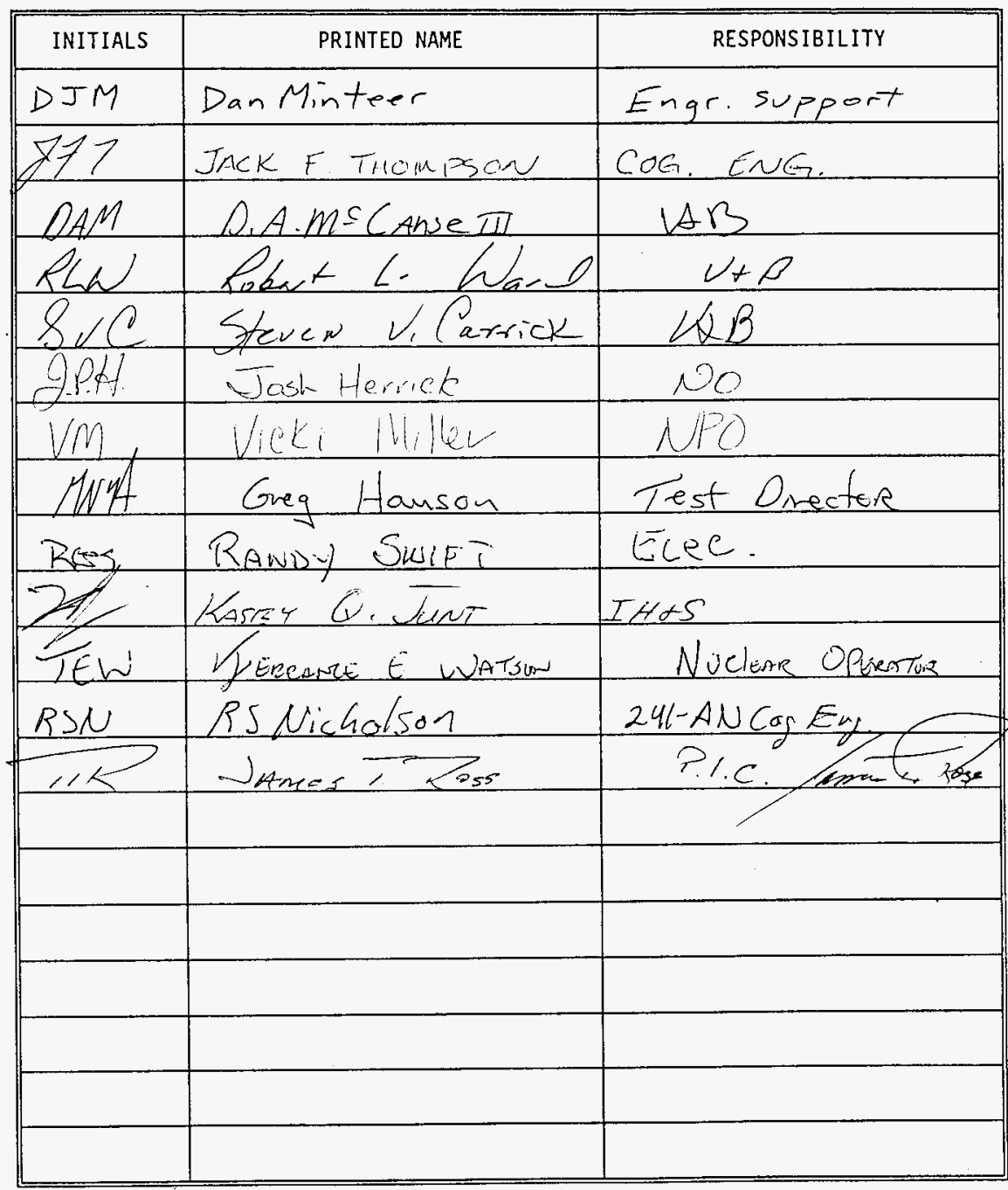

B-16 
DATA SHEET 1

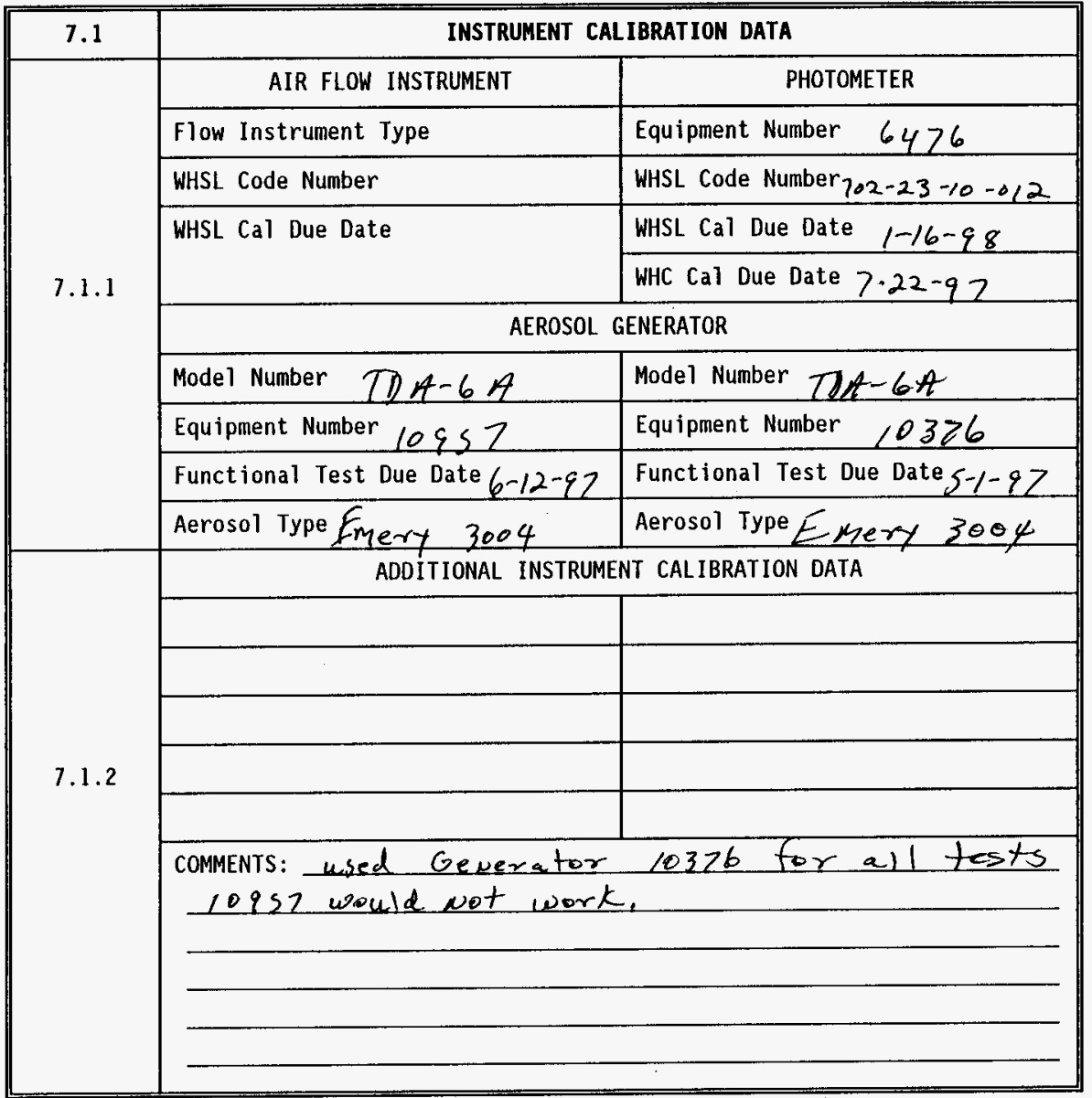

Initials/Date $\frac{\ln (1-28 \times 9697}{\substack{2 \pi \\ 1-2497}}$ 


\section{DATA SHEET 2}

\begin{tabular}{|c|c|c|c|c|}
\hline STEP 7.2 & VISUAL INSPECTION CHECKLIST & YES & NO & $N / A$ \\
\hline \multirow{12}{*}{7.2 .1} & Filter housing access adequate? & $x$ & & \\
\hline & Housekeeping adequate? & $x$ & & \\
\hline & Lighting levels adequate? & $x$ & & \\
\hline & Housing or ductwork damaged? & & $\chi$ & \\
\hline & Test ports available (Figures $1 \& 2$ )? & $x$ & & \\
\hline & Test ports labeled? & $x$ & & \\
\hline & Housing door or seal damaged or leaking? & & $x$ & \\
\hline & Installed pressure gauges labeled? & $x$ & & \\
\hline & Calibration labels current? & $x$ & & \\
\hline & Instrumentation damaged (broken, disconnected)? & & $x$ & \\
\hline & Filter damaged (tears, holes, frame separation)? & & $x$ & \\
\hline & Evidence of moisture in housing (stains, water)? & & $x$ & \\
\hline \multirow{6}{*}{7.2 .2} & \multicolumn{4}{|l|}{ COMMENTS: } \\
\hline & & & & \\
\hline & & & & \\
\hline & & & & \\
\hline & & & & \\
\hline & & & & \\
\hline
\end{tabular}

Initials/Date fuc $1-2 g-97$ 
DATA SHEET 3 (Sheet 1 of 2)

\begin{tabular}{|c|c|c|c|c|c|c|}
\hline STEP 7.3 & \multicolumn{6}{|c|}{ DIFFERENTIAL PRESSURE READINGS } \\
\hline \multirow{16}{*}{7.3 .1} & FILTER* & DP GAUGE* & LOCATION & $\begin{array}{l}\text { READING } \\
\text { (in. wg) }\end{array}$ & $\begin{array}{l}\text { LIMITS } \\
\text { (in. wg) }\end{array}$ & RESULTS \\
\hline & \multicolumn{6}{|c|}{ 24l-AN-101 TANK INLET } \\
\hline & $\begin{array}{l}\text { Prefilter } \\
\text { FLT-101A }\end{array}$ & PDI-113A & \multirow{2}{*}{$\begin{array}{l}\text { Inlet } \\
\text { Filter }\end{array}$} & .30 & $\begin{array}{l}0.01 \mathrm{~min} \\
1.00 \mathrm{max}\end{array}$ & $\begin{array}{l}\text { PASS } \\
\text { FAIL }\end{array}$ \\
\hline & $\begin{array}{c}\text { HEPA } \\
\text { FLT-101B }\end{array}$ & PDI-114A & & 0 & $\begin{array}{l}0.10 \min \\
2.00 \max \end{array}$ & $\stackrel{\text { PASS }}{\text { GAIZ }}$ \\
\hline & \multicolumn{6}{|c|}{ 241-AN-102 TANK INLET } \\
\hline & $\begin{array}{l}\text { Prefilter } \\
\text { FLT-102A }\end{array}$ & PDI-113B & \multirow{2}{*}{$\begin{array}{l}\text { Inlet } \\
\text { Filter }\end{array}$} & .02 & $\begin{array}{l}0.01 \min \\
1.00 \max \end{array}$ & $\begin{array}{l}\text { FASS } \\
\text { FAIL }\end{array}$ \\
\hline & $\begin{array}{l}\text { HEPA } \\
\text { FLT-102B }\end{array}$ & PDI-114B & & .19 & $\begin{array}{l}0.10 \min \\
2.00 \max \end{array}$ & $\frac{\text { PASS }}{\text { FAIL }}$ \\
\hline & \multicolumn{6}{|c|}{ 241-AN-103 TANK INLET } \\
\hline & $\begin{array}{l}\text { Prefilter } \\
\text { FLT-103A }\end{array}$ & PDI $-113 \mathrm{C}$ & \multirow{2}{*}{$\begin{array}{l}\text { Inlet } \\
\text { Filter }\end{array}$} & .10 & $\begin{array}{l}0.01 \mathrm{~min} \\
1.00 \max \end{array}$ & $\frac{\text { PASS }}{\text { FAIL }}$ \\
\hline & $\begin{array}{l}\text { HEPA } \\
\text { FLT-103B }\end{array}$ & PDI-114C & & .20 & $\begin{array}{l}0.10 \min \\
2.00 \max \end{array}$ & $\frac{\text { PASS }}{\text { FAIL }}$ \\
\hline & \multicolumn{6}{|c|}{ 241-AN-104 TANK INLET } \\
\hline & $\begin{array}{l}\text { Prefilter } \\
\text { FLT-104A }\end{array}$ & PDI-1130 & \multirow{2}{*}{$\begin{array}{l}\text { Inlet } \\
\text { Filter }\end{array}$} & 0 & $\begin{array}{l}0.01 \mathrm{~min} \\
1.00 \mathrm{max}\end{array}$ & PASS \\
\hline & $\begin{array}{l}\text { HEPA } \\
\text { FLT-1048 }\end{array}$ & PDI-1140 & & .16 & $\begin{array}{l}0.10 \mathrm{~min} \\
2.00 \mathrm{max}\end{array}$ & $\begin{array}{l}\text { CASS } \\
\text { FAIL }\end{array}$ \\
\hline & \multicolumn{6}{|c|}{ 241-AN-105 TANK INLET } \\
\hline & $\begin{array}{l}\text { Prefilter } \\
\text { FLT-105A }\end{array}$ & PDI-113E & \multirow{2}{*}{$\begin{array}{l}\text { Inlet } \\
\text { Filter }\end{array}$} & .03 & $\begin{array}{l}0.01 \mathrm{~min} \\
1.00 \max \end{array}$ & $\begin{array}{l}\text { EASS } \\
\text { FAIL }\end{array}$ \\
\hline & $\begin{array}{c}\text { HEPA } \\
\text { FLT-105B }\end{array}$ & PDI-114E & & .19 & $\begin{array}{l}0.10 \min \\
2.00 \max \end{array}$ & $\frac{\text { PASS - }}{\text { FAIL }}$ \\
\hline
\end{tabular}

* Equipment designations as labeled in field are prefixed by "VTP-".

Initials/Date $\& \mu \quad 1-28-97$ 
DATA SHEET 3 (Sheet 2 of 2)

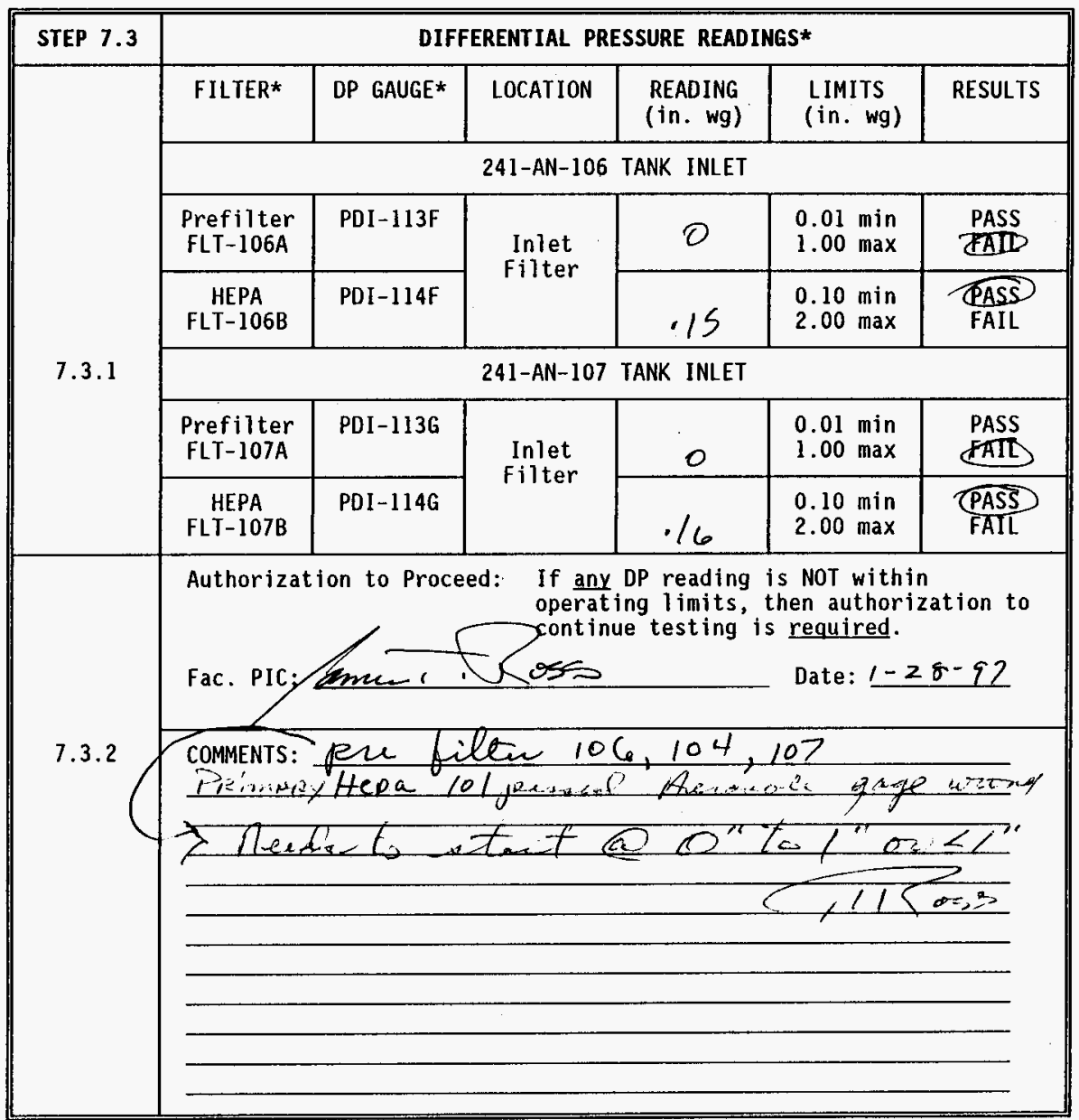

* Equipment designations as labeled in field are prefixed by "VTP-".

Initials/Date sue 1-28-97 
PROC. NO. 6-TF-156-TV

REV. 0, CHG. 0

PAGE 7 of 23

\begin{tabular}{|l|c|}
\hline \multicolumn{2}{|c|}{ 241-AN TANK INLET } \\
\hline MEASUREMENT & TEST PORT \\
\hline Velocity Pressure & C, D \\
\hline Duct Diometer: & 12 in. (i.d.) \\
\hline Duct Area: & $0.79 \mathrm{sq} \mathrm{ft}$ \\
\hline
\end{tabular}

NOTE:

PITOT TRAVERSES ARE NOT TAKEN UNLESS DIRECTED BY COG ENGINEER.

INLET AIR FLOW IS DETERMINED BY

FLOW CONTROLLER ORIFICE PLATE

SIZE (SEE H-2-85647-3).

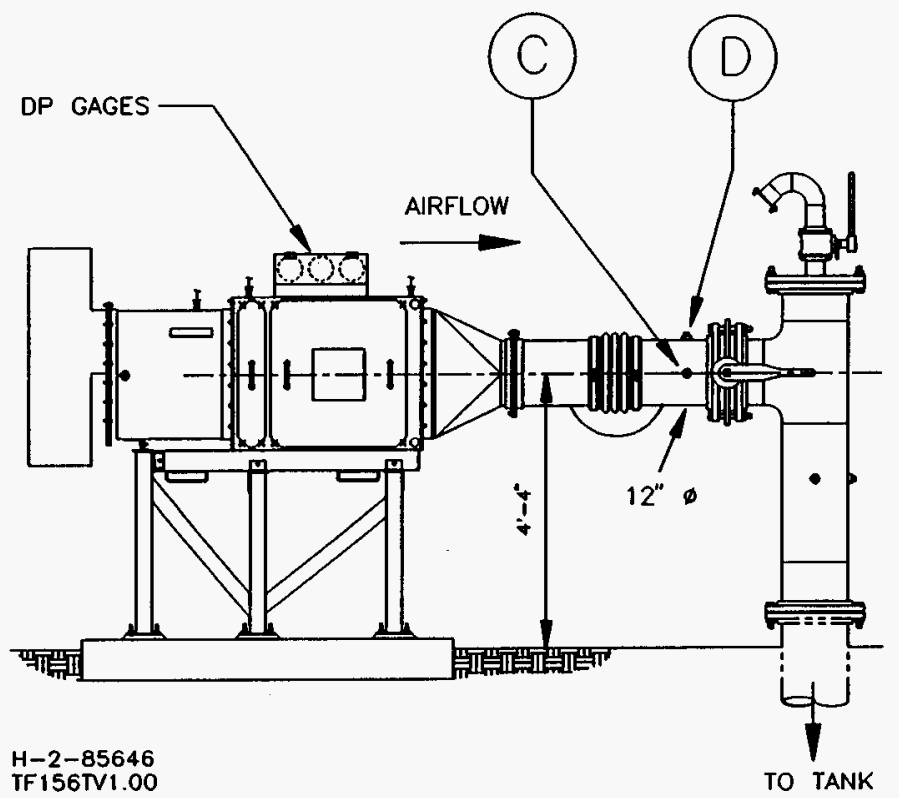

Figure 1. 241-AN Tank Inlet Air Flow Test Ports (Typical). 


\section{DATA SHEET 4 (Sheet 1 of 7) \\ 241-AN-101 TANK INLET}

\begin{tabular}{|c|c|c|c|c|c|}
\hline STEP 7.4 & \multicolumn{5}{|c|}{ SYSTEM AIR FLOW READINGS } \\
\hline \multirow{2}{*}{--} & \multicolumn{5}{|c|}{$\begin{array}{l}\text { STEPS } 7.4 .1 \text { THRU } 7.4 .6 \text { DO NOT APPLY UHLESS DIRECTED BY THE COGNIZANI ENGINEER. } \\
\text { ENTER ORIFICE PLATE MUMBER AMO MOHIHAL FLOW FROH SCHEDULE SHOWN ON H-2-85647, SHEET } 3 .\end{array}$} \\
\hline & PLATE \# & 16 & NOMINAL A & OW (CFM) & 125 \\
\hline \multirow{12}{*}{$\begin{array}{l}7.4 .1 \\
7.4 .2 \\
7.4 .3\end{array}$} & \multirow{2}{*}{$\begin{array}{l}\text { Traverse } \\
\text { Points* } \\
\text { (in.) }\end{array}$} & \multicolumn{2}{|c|}{ PORT C } & \multicolumn{2}{|c|}{ PORT D } \\
\hline & & $\begin{array}{c}\text { VP } \\
\text { (in. wg) }\end{array}$ & $\begin{array}{l}\text { Velocity** } \\
\text { (fpm) }\end{array}$ & $\begin{array}{l}\text { VP } \\
\text { (in. wg) }\end{array}$ & $\begin{array}{c}\text { Velocity** } \\
(\text { fpm) }\end{array}$ \\
\hline & $1 / 2$ & & & & \\
\hline & 1 & & & & \\
\hline & $13 / 4$ & & & & \\
\hline & $23 / 4$ & & & & \\
\hline & $41 / 8$ & & & & \\
\hline & $77 / 8$ & & & & \\
\hline & $91 / 4$ & & & & \\
\hline & $101 / 4$ & & & & \\
\hline & 11 & & & & \\
\hline & $111 / 2$ & & & & \\
\hline \multirow{2}{*}{7.4 .4} & \multicolumn{2}{|c|}{ Port Totals/fpm) } & & & \\
\hline & \multicolumn{3}{|c|}{ Total form $=$ Total Port $C+$ Total Port $D$} & & \\
\hline 7.4 .5 & \multicolumn{3}{|c|}{ Average $\mathrm{fpm}=$ Total $\mathrm{fpm}+20$} & & \\
\hline 7.4 .6 & \multicolumn{4}{|c|}{ Blr flow $(\mathrm{cfm})=$ Average $\mathrm{fpm} \times 0.79 \mathrm{sq} \mathrm{ft}$} & \\
\hline
\end{tabular}

* Ten-point traverse per ACGIH 9 measured relative to internal diameter (i.d.); no points to be located within $0.5 \mathrm{in}$. of stack walls (40 CFR 60, App. A).

${ }^{* *} \mathrm{FPM}=4005 \sqrt{\mathrm{VP}}$

Initials/Date Sec 1-28-97 
DATA SHEET 4 (Sheet 2 of 7)

241-AN-102 TANK INLET

\begin{tabular}{|c|c|c|c|c|c|}
\hline STEP 7.4 & \multicolumn{5}{|c|}{ SYSTEM AIR FLOW READINGS } \\
\hline \multirow{2}{*}{--} & \multicolumn{5}{|c|}{$\begin{array}{l}\text { STEPS } 7.4 .1 \text { THRU } 7.4 .6 \text { DO NOT APPLY UNLESS OIRECTED BY JHE COGNIZANT ENGINEER. } \\
\text { ENTER ORIFICE PLATE MUMBER AHD NOMIHAL FLOW FROM SCHEDULE SHOUN ON H-2-85647, SMEET } 3 .\end{array}$} \\
\hline & PLATE \# & $/ 6$ & \multicolumn{2}{|c|}{ NOMINAL AIR FLOW (CFM) } & 125 \\
\hline \multirow{12}{*}{$\begin{array}{l}7.4 .1 \\
7.4 .2 \\
7.4 .3\end{array}$} & \multirow{2}{*}{$\begin{array}{c}\text { Traverse } \\
\text { Points* } \\
\text { (in.) }\end{array}$} & \multicolumn{2}{|c|}{ PORT C } & \multicolumn{2}{|c|}{ PORT D } \\
\hline & & $\begin{array}{l}\text { VP } \\
\text { (in. wg) }\end{array}$ & $\begin{array}{l}\text { Velocity** } \\
(\mathrm{fpm})\end{array}$ & $\begin{array}{l}\text { VP } \\
\text { (in. wg) }\end{array}$ & $\begin{array}{l}\text { Velocity** } \\
\text { (fpm) }\end{array}$ \\
\hline & $1 / 2$ & & & & \\
\hline & 1 & & & & \\
\hline & $13 / 4$ & & & & \\
\hline & $23 / 4$ & & & & \\
\hline & $41 / 8$ & & & & \\
\hline & $77 / 8$ & & & & \\
\hline & $91 / 4$ & & & & \\
\hline & $101 / 4$ & & & & \\
\hline & 11 & & & & \\
\hline & $111 / 2$ & & & & \\
\hline \multirow{2}{*}{7.4 .4} & \multicolumn{2}{|c|}{ Port Totals (fpm) } & & & \\
\hline & \multicolumn{3}{|c|}{ Total fpm $=$ Total Port $C+$ Total Port D } & & \\
\hline 7.4 .5 & \multicolumn{3}{|c|}{ Average $\mathrm{fpm}=$ Total $\mathrm{fpm} \div 20$} & & \\
\hline 7.4 .6 & \multicolumn{4}{|c|}{ Air flow $(\mathrm{cfm})=$ Average $\mathrm{fpm} \times 0.79 \mathrm{sq} \mathrm{ft}$} & \\
\hline
\end{tabular}

* Ten-point traverse per ACGIH 9 measured relative to internal diameter (i.d.); no points to be located within $0.5 \mathrm{in}$. of stack walls ( 40 CFR 60 , App. A). ** $\mathrm{FPM}=4005 \sqrt{\mathrm{VP}}$ 


\section{DATA SHEET 4 (Sheet 3 of 7) \\ 241-AN-103 TANK INLET}

\begin{tabular}{|c|c|c|c|c|c|}
\hline STEP 7.4 & \multicolumn{5}{|c|}{ SYSTEM AIR FLOH READINGS } \\
\hline \multirow{2}{*}{--} & \multicolumn{5}{|c|}{$\begin{array}{l}\text { STEPS } 7.4 .1 \text { THRU } 7.4 .6 \text { DO MOT APPLY UNLESS DIRECTED BY THE COCNIZANT ENGINEER. } \\
\text { ENTER ORIFICE PLATE NUMBER AND NOHINAL FLOW FROH SCHEDULE SHOWH ON H-2-85647, SHEET } 3 .\end{array}$} \\
\hline & \multirow{3}{*}{$\begin{array}{c}\text { PLATE \# } \\
\text { Traverse } \\
\text { Points* } \\
\text { (in.) }\end{array}$} & 16 & \multicolumn{2}{|c|}{ NOMINAL AIR FLOW (CFM) } & 125 \\
\hline \multirow{12}{*}{$\begin{array}{l}7.4 .1 \\
7.4 .2 \\
7.4 .3\end{array}$} & & \multicolumn{2}{|c|}{ PORT C } & \multicolumn{2}{|c|}{ PORT D } \\
\hline & & $\begin{array}{c}\text { VP } \\
\text { (in. wg) }\end{array}$ & $\begin{array}{l}\text { Velocity** } \\
\text { (fpm) }\end{array}$ & $\begin{array}{c}V P \\
\text { (in. wg) }\end{array}$ & $\begin{array}{l}\text { Velocity** } \\
(\text { fpm) }\end{array}$ \\
\hline & $1 / 2$ & & & & \\
\hline & 1 & & & & \\
\hline & $13 / 4$ & & & & \\
\hline & $23 / 4$ & & & & \\
\hline & $41 / 8$ & & & & \\
\hline & $77 / 8$ & & & & \\
\hline & $91 / 4$ & & & & \\
\hline & $101 / 4$ & & & & \\
\hline & 11 & & & & \\
\hline & $111 / 2$ & & & & \\
\hline & Port Tota & (pin) & & & \\
\hline 1.4 .4 & Total fpm & tal Port & Total Port D & & \\
\hline 7.4 .5 & Average $f$ & Total $f p r$ & & & \\
\hline 7.4 .6 & Air flow & $=$ Avera & $\mathrm{n} \times 0.79 \mathrm{sq} f$ & & \\
\hline
\end{tabular}

* Ten-point traverse per ACGIH 9 measured relative to internal diameter (i.d.); no points to be located within 0.5 in. of stack walls (40 CFR 60, App. A).

${ }_{\star \star *} \mathrm{FPM}=4005 \sqrt{\mathrm{VP}}$

Initials/Date $4 \Omega \quad 1-28-97$ 


\section{DATA SHEET 4 (Sheet 4 of 7) \\ 241-AN-104 TANK INLET}

\begin{tabular}{|c|c|c|c|c|c|}
\hline STEP 7.4 & \multicolumn{5}{|c|}{ SYSTEM AIR FLOW READINGS } \\
\hline \multirow[t]{2}{*}{--} & \multicolumn{5}{|c|}{$\begin{array}{l}\text { STEPS } 7.4 .1 \text { THRU } 7.4 .6 \text { DO NOT APPLY UHLESS DIRECTED BY THE COGHIZANT ENGINEER. } \\
\text { ENTER ORIFICE PLATE NUMBER ANO NOMINAL FLOH FROM SCHEDULE SHOWN ON H-2-85647, SHEET } 3 .\end{array}$} \\
\hline & PLATE \# & 16 & \multicolumn{2}{|c|}{ NOMINAL AIR FLOW (CFM) } & 125 \\
\hline \multirow{12}{*}{$\begin{array}{l}7.4 .1 \\
7.4 .2 \\
7.4 .3\end{array}$} & \multirow{2}{*}{$\begin{array}{l}\text { Traverse } \\
\text { Points* } \\
\text { (in.) }\end{array}$} & \multicolumn{2}{|c|}{ PORT C } & \multicolumn{2}{|c|}{ PORT D } \\
\hline & & $\begin{array}{c}\text { VP } \\
\text { (in. wg) }\end{array}$ & $\begin{array}{l}\text { Velocity** } \\
\text { (fpm) }\end{array}$ & $\begin{array}{l}\text { VP } \\
\text { (in. } w g)\end{array}$ & $\begin{array}{l}\text { Velocity** } \\
(\mathrm{fpm})\end{array}$ \\
\hline & $1 / 2$ & & & & \\
\hline & 1 & & & & \\
\hline & $13 / 4$ & & & & \\
\hline & $23 / 4$ & & & & \\
\hline & $41 / 8$ & & & & \\
\hline & $77 / 8$ & & & & \\
\hline & $91 / 4$ & & & & \\
\hline & $101 / 4$ & & & & \\
\hline & 11 & & & & \\
\hline & $111 / 2$ & & & & \\
\hline \multirow{2}{*}{7.4 .4} & \multicolumn{2}{|c|}{ Port Totals (fprif) } & & & \\
\hline & \multicolumn{3}{|c|}{ Total fpm $=$ Total Port $C+$ Total Port $D$} & & \\
\hline 7.4 .5 & \multicolumn{3}{|c|}{ Avergge $\mathrm{fpm}=$ Total $\mathrm{fpm}+20$} & & \\
\hline 7.4 .6 & \multicolumn{4}{|c|}{ Air $\mathrm{flow}(\mathrm{cfm})=$ Average $\mathrm{fpm} \times 0.79 \mathrm{sq} \mathrm{ft}$} & \\
\hline
\end{tabular}

* Ten-point traverse per ACGIH 9 measured relative to internal diameter (i.d.); no points to be located within 0.5 in. of stack walls (40 CFR 60, App. A).

${ }^{\star \star} \mathrm{FPM}=4005 \sqrt{\mathrm{VP}}$ 
HNF-SD-WM-0TR-215 Rev. 0

WTP MAINTENANCE PROCEDURE DATA SHEET

241-AN TANK INLET FILTER

PROC. NO. 6-TF-156-TV

AEROSOL TEST DATA SHEETS

REV. O, CHG. 0

PAGE 12 of 23

DATA SHEET 4 (Sheet 5 of 7)

241-AN-105 TANK INLET

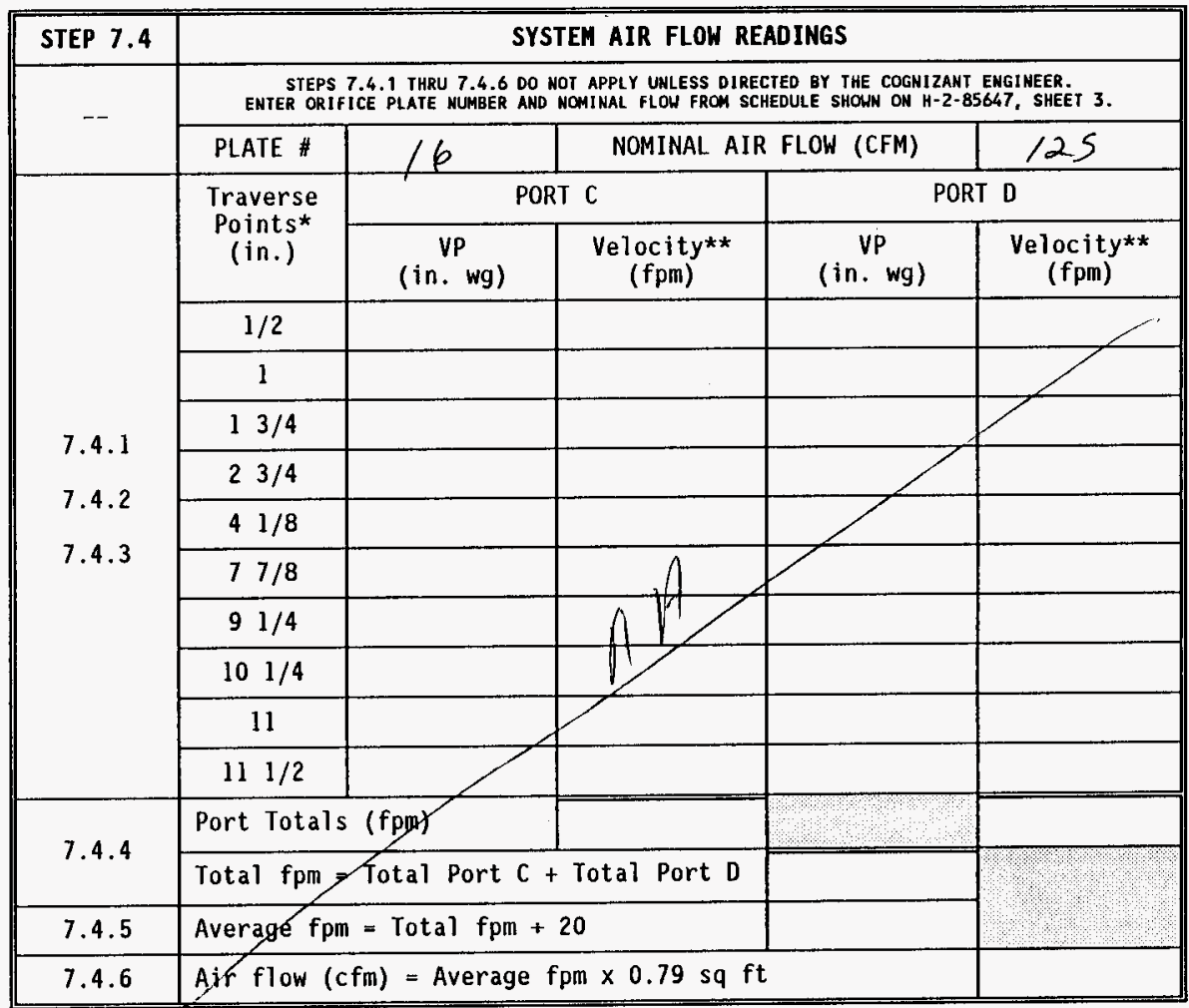

* Ten-point traverse per ACGIH 9 measured relative to internal diameter (i.d.); no points to be located within 0.5 in. of stack walls (40 CFR 60, App. A).

** FPM $=4005 \sqrt{\text { VP }}$

Initials/Date \&ue $1-28-97$ 
DATA SHEET 4 (Sheet 6 of 7)

241-AN-106 TANK INLET

\begin{tabular}{|c|c|c|c|c|c|}
\hline STEP 7.4 & \multicolumn{5}{|c|}{ SYSTEM AIR FLOW READINGS } \\
\hline \multirow{2}{*}{--} & \multicolumn{5}{|c|}{$\begin{array}{l}\text { STEPS 7.4.1 THRU 7.4.6 DO NOT APPLY UNLESS DIRECTED BY THE COGNIZANT ENGINEER. } \\
\text { ENTER ORIFICE PLATE NUMBER AND MOMINAL FLOW FROH SCHEDULE SHOWN ON H-2-85647, SHEEI } 3 .\end{array}$} \\
\hline & PLATE \# & 16 & \multicolumn{2}{|c|}{ NOMINAL AIR FLOW (CFM) } & 125 \\
\hline \multirow{12}{*}{$\begin{array}{l}7.4 .1 \\
7.4 .2 \\
7.4 .3\end{array}$} & \multirow{2}{*}{$\begin{array}{c}\text { Traverse } \\
\text { Points* } \\
\text { (in.) }\end{array}$} & \multicolumn{2}{|c|}{ PORT C } & \multicolumn{2}{|c|}{ PORT D } \\
\hline & & $\begin{array}{l}\text { VP } \\
\text { (in. wg) }\end{array}$ & $\begin{array}{l}\text { Velocity**} \\
\text { (fpm) }\end{array}$ & $\begin{array}{l}\text { VP } \\
\text { (in. wg) }\end{array}$ & $\begin{array}{l}\text { Velocity** } \\
\text { (fpm) }\end{array}$ \\
\hline & $1 / 2$ & & & & \\
\hline & 1 & & & & , \\
\hline & $13 / 4$ & & & & \\
\hline & $23 / 4$ & & & & \\
\hline & $41 / 8$ & & & & \\
\hline & $77 / 8$ & & & & \\
\hline & $91 / 4$ & & & & \\
\hline & $101 / 4$ & & & & \\
\hline & 11 & & & & \\
\hline & $111 / 2$ & & & & \\
\hline \multirow{2}{*}{7.4 .4} & \multicolumn{2}{|c|}{ Port Totals (fpm) } & & & \\
\hline & \multicolumn{3}{|c|}{ Total $f p m=$ Iotal Port $C+$ Total Port D } & & \\
\hline 7.4 .5 & \multicolumn{3}{|c|}{ Average $f \mathrm{pm}=$ Total $\mathrm{fpm}+20$} & & \\
\hline 7.4 .6 & \multicolumn{4}{|c|}{ Air flow $(\mathrm{cfm})=$ Average $\mathrm{fpm} \times 0.79 \mathrm{sq} \mathrm{ft}$} & \\
\hline
\end{tabular}

* Ten-point traverse per ACGIH 9 measured relative to internal diameter (i.d.); no points to be located within 0.5 in. of stack walls (40 CFR 60, App. A). ** $\mathrm{FPM}=4005 \sqrt{\mathrm{VP}}$ 
DATA SHEET 4 (Sheet 7 of 7)

241-AN-107 TANK INLET

\begin{tabular}{|c|c|c|c|c|c|}
\hline STEP 7.4 & \multicolumn{5}{|c|}{ SYSTEM AIR FLOW READINGS } \\
\hline \multirow{2}{*}{--} & \multicolumn{5}{|c|}{$\begin{array}{l}\text { STEPS } 7.4 .1 \text { THRU } 7.4 .6 \text { DO NOT APPLY UMLESS DIRECIED BY THE COGNIZANT ENGINEER. } \\
\text { ENTER ORIFICE PLATE MUMBER AMD NOMINAL FLOW FROM SCHEOULE SHOWN ON H-2-85647, SHEET } 3 .\end{array}$} \\
\hline & PLATE \# & 16 & \multicolumn{2}{|c|}{ NOMINAL AIR FLOW (CFM) } & 125 \\
\hline \multirow{6}{*}{7.4 .1} & \multirow{2}{*}{$\begin{array}{c}\text { Traverse } \\
\text { Points* } \\
\text { (in.) }\end{array}$} & \multicolumn{2}{|c|}{ PORT C } & \multicolumn{2}{|c|}{ PORT D } \\
\hline & & $\begin{array}{l}\text { VP } \\
\text { (in. wg) }\end{array}$ & $\begin{array}{l}\text { Velocity**} \\
(\text { fpm) }\end{array}$ & $\begin{array}{l}\text { VP } \\
\text { (in. wg) }\end{array}$ & $\begin{array}{l}\text { Velocity**} \\
\text { (fpm) }\end{array}$ \\
\hline & $1 / 2$ & & & & \\
\hline & 1 & & & & \\
\hline & $13 / 4$ & & & & \\
\hline & $23 / 4$ & & & & \\
\hline 7.4 .2 & $41 / 8$ & & & & \\
\hline \multirow{5}{*}{7.4 .3} & $77 / 8$ & & & & \\
\hline & $91 / 4$ & & & & \\
\hline & $101 / 4$ & & & & \\
\hline & 11 & & & & \\
\hline & $111 / 2$ & & & & \\
\hline \multirow{2}{*}{7.4 .4} & \multicolumn{2}{|c|}{ Port Totals (fpm) } & & & \\
\hline & \multicolumn{3}{|c|}{ Total fpm $=$ Jotal Port $C+$ Total Port $D$} & & \\
\hline 7.4 .5 & \multicolumn{3}{|c|}{ Average $f \mathrm{pm}=$ Total $\mathrm{fpm}+20$} & & \\
\hline 7.4 .6 & \multicolumn{4}{|c|}{ Aip flow $(\mathrm{cfm})=$ Average $\mathrm{fpm} \times 0.79 \mathrm{sq} \mathrm{ft}$} & \\
\hline
\end{tabular}

* Ten-point traverse per ACGIH 9 measured relative to internal diameter (i.d.); no points to be located within 0.5 in. of stack walls (40 CFR 60, App. A).

** $\mathrm{FPM}=4005 \sqrt{\mathrm{VP}}$

$$
\text { Initials/Date fu } 1-28-97
$$


REV. O, CHG. 0

PAGE 15 of 23

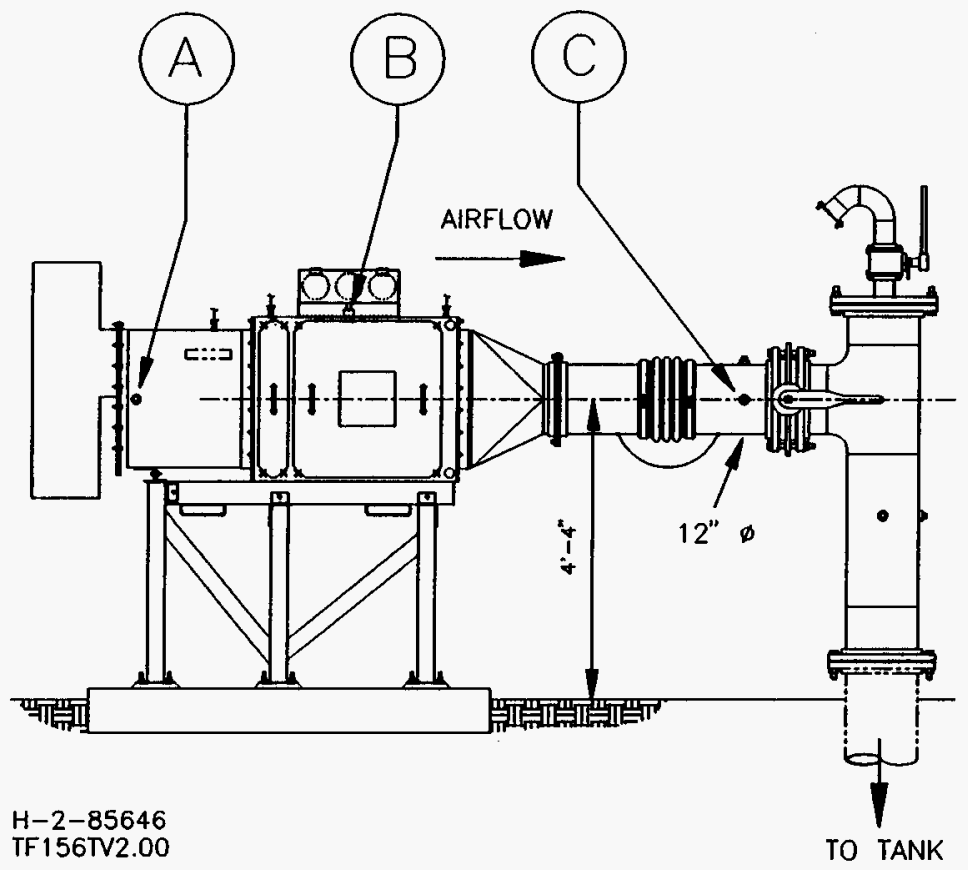

\begin{tabular}{|c|l|c|}
\hline \multirow{2}{*}{ TEST } & PORT & $\begin{array}{c}\text { HEPA FILTER VTP-FLT } \\
\text { 1018 THRU 1078 }\end{array}$ \\
\hline \multirow{2}{*}{ BASELINE } & INJECT & $\mathrm{A}$ \\
\cline { 2 - 3 } & SAMPLE & $\mathrm{B}$ \\
\hline \multirow{2}{*}{ PENETRATION } & INJECT & $\mathrm{A}$ \\
\cline { 2 - 3 } & SAMPLE & $\mathrm{C}$ \\
\hline
\end{tabular}

Figure 2. 24l-AN Tank Inlet Filter Test Ports (Typical). 


\section{DATA SHEET 5 (Sheet 1 of 7)}

241-AN-101 TANK INLET FILTER VTP-FLT-101B

\begin{tabular}{|c|c|c|c|}
\hline STEP 7.5 & \multicolumn{3}{|c|}{ AEROSOL TEST READINGS } \\
\hline \multirow{2}{*}{7.5 .1} & TRIAL 1 & TRIAL 2 & TRIAL 3 \\
\hline & Generator: $N / A$ psi & Generator: $N / \mathbb{A}$ psi & Generator: $\mu / A$ psi \\
\hline 7.5 .2 & $\begin{array}{l}\text { (scale } \times \text { Reading }=\text { Eq. Input) } \\
100 \times 100=10000 \mathrm{c} b\end{array}$ & $\begin{array}{l}\text { (Scale } \times \text { Reading }=\text { Eq. Input) } \\
100 \times 100=10000 \mathrm{cb}\end{array}$ & $\begin{array}{l}\text { (scale } \times \text { Reading }=\text { Eq. Input) } \\
100 \times 100=10000 \mathrm{c}_{\mathrm{b}}\end{array}$ \\
\hline 7.5 .3 & $\begin{array}{l}100 \times 0=-0 \\
.1 \times 0=0\end{array}$ & $\begin{array}{l}100 \times 0=0 \\
11 \times 0=0\end{array}$ & $\begin{array}{l}100 \times \underline{0}=0 \quad \mathrm{~B}_{\mathrm{b}} \\
11 \times \underline{0}=0 \quad \mathrm{~B}_{\mathrm{p}}\end{array}$ \\
\hline 7.5 .4 & $-1 \times \underline{2}=.2 c_{p}$ & $.1 \times 2=.2 c_{p}$ & $11 \times \underline{2}=, 2=c_{p}$ \\
\hline STEP 7.8 & \multicolumn{3}{|c|}{ AEROSOL PENETRATION CALCULATIONS ${ }^{*}$} \\
\hline 7.8 .1 & $\begin{array}{c}P=100\left(\frac{C_{p}}{C_{b}}\right) \\
P=100\left(\frac{.2}{10000}\right) \\
P=.002\end{array}$ & $\begin{array}{c}P=100\left(\frac{C_{p}}{C_{b}}\right) \\
P=100\left(\frac{.2}{10000}\right) \\
P=.002\end{array}$ & $\begin{array}{c}P=100\left(\frac{C_{P}}{C_{b}}\right) \\
P=100\left(\frac{.2}{10000}\right) \\
P=, 002\end{array}$ \\
\hline \multirow{2}{*}{7.8 .2} & \multicolumn{3}{|c|}{ PASS $=P<0.05 \% \quad$ FAlL $=P \geq 0.05 \%$} \\
\hline & $\angle \mathrm{PASS} 7 \mathrm{FAIL}$ & PASS / FAIL & PASS FAIL \\
\hline 7.8 .3 & \multicolumn{3}{|c|}{ Fac. PIC signature required if ANY trial fails: } \\
\hline
\end{tabular}

* Background concentrations $\left(B_{b}, B_{p}\right)$ are for information only and are not part of percent penetration calculation. 
HNF-SD-WM-0TR-215 Rev. 0

WTP MAINTENANCE PROCEDURE DATA SHEET

241-AN TANK INLET FILTER

AEROSOL. TEST DATA SHEETS

PROC. NO. 6-TF-156-TV

REV. 0 , CHG. 0

PAGE 17 of 23

DATA SHEET 5 (Sheet 2 of 7)

241-AN-102 TANK INLET FILTER VTP-FLT-102B

\begin{tabular}{|c|c|c|c|}
\hline STEP 7.5 & \multicolumn{3}{|c|}{ AEROSOL TEST READINGS } \\
\hline \multirow{2}{*}{7.5 .1} & TRIAL 1 & TRIAL 2 & TRIAL 3 \\
\hline & Generator: $N / A$ psi & Generator: $N / A$ psi & Generator: $\psi / A$ psi \\
\hline 7.5 .2 & $\begin{array}{l}\text { (Scale } \times \text { Reading }=\text { Eq. Input) } \\
100 \times 100=10000 \mathrm{c}_{\mathrm{b}}\end{array}$ & $\begin{array}{l}\text { (Scale } \times \text { Reading }=\text { Eq. Input) } \\
100 \times 100=10000 c_{b}\end{array}$ & $\begin{array}{l}\text { (scale } \times \text { Reading }=\text { Eq. Input) } \\
100 \times 100=10000 \mathrm{c}_{\mathrm{b}}\end{array}$ \\
\hline 7.5 .3 & $\begin{array}{l}100 \times 0=0 \\
11 \times 0=0\end{array}$ & $\begin{array}{l}100 \times 0=0 \\
11 \times 0=0\end{array}$ & $\begin{array}{l}100 \times 0=0 \\
.1 \times 10=0\end{array}$ \\
\hline 7.5 .4 & $.1 \times 2 \times 2=.2 c_{p}$ & $.1 \times 2=.2 c_{p}$ & $.1 \times 2=.2 c_{p}$ \\
\hline STEP 7.8 & \multicolumn{3}{|c|}{$\begin{array}{l}\text { AEROSOL PENETRATION CALCULATIONS* } \\
\end{array}$} \\
\hline 7.8 .1 & $\begin{array}{c}P=100\left(\frac{C_{p}}{C_{b}}\right) \\
P=100\left(\frac{.2}{10000}\right) \\
P=, 002\end{array}$ & $\begin{array}{c}P=100\left(\frac{C_{p}}{C_{b}}\right) \\
P=100\left(\frac{12}{10000}\right) \\
P=.002\end{array}$ & $\begin{array}{c}P=100\left(\frac{C_{P}}{C_{b}}\right) \\
P=100\left(\frac{.2}{10000}\right) \\
P=.0028\end{array}$ \\
\hline \multirow[b]{2}{*}{7.8 .2} & \multicolumn{3}{|c|}{ PASS $=P<0.05 \% \quad$ FAIL $=P \geq 0.05 \%$} \\
\hline & PASS / FAIL & CAASS I FAIL & (PASS) / FAI \\
\hline 7.8 .3 & \multicolumn{3}{|c|}{$\begin{array}{l}\text { Fac. PIC signature required if ANY trial fails: } \\
\text { Fac. PIC Date: }\end{array}$} \\
\hline
\end{tabular}

* Background concentrations $\left(B_{b}, B_{p}\right)$ are for information only and are not part of percent penetration calculation.

Initials/Date $\mathrm{S} \mu(-28-97$ 


\begin{tabular}{|c|c|c|}
\hline Post-It' Fax Note & 7671 & Date, $-29-9 d_{\text {peges }}^{\text {Bl }}$ \\
\hline${ }^{\text {To }}$ suek & & From o ossce \\
\hline coldept Ereg & & co. \\
\hline Fhone \# & & Phone \\
\hline FaxA- $5-2 Z$ & & Fax\# \\
\hline
\end{tabular}

NO. 6-TF-156-TV

0 , CHG. $\mathrm{O}$

18 of 23

\section{1-AN-103 TANK INLET FILTER VTP-FLT-103B}

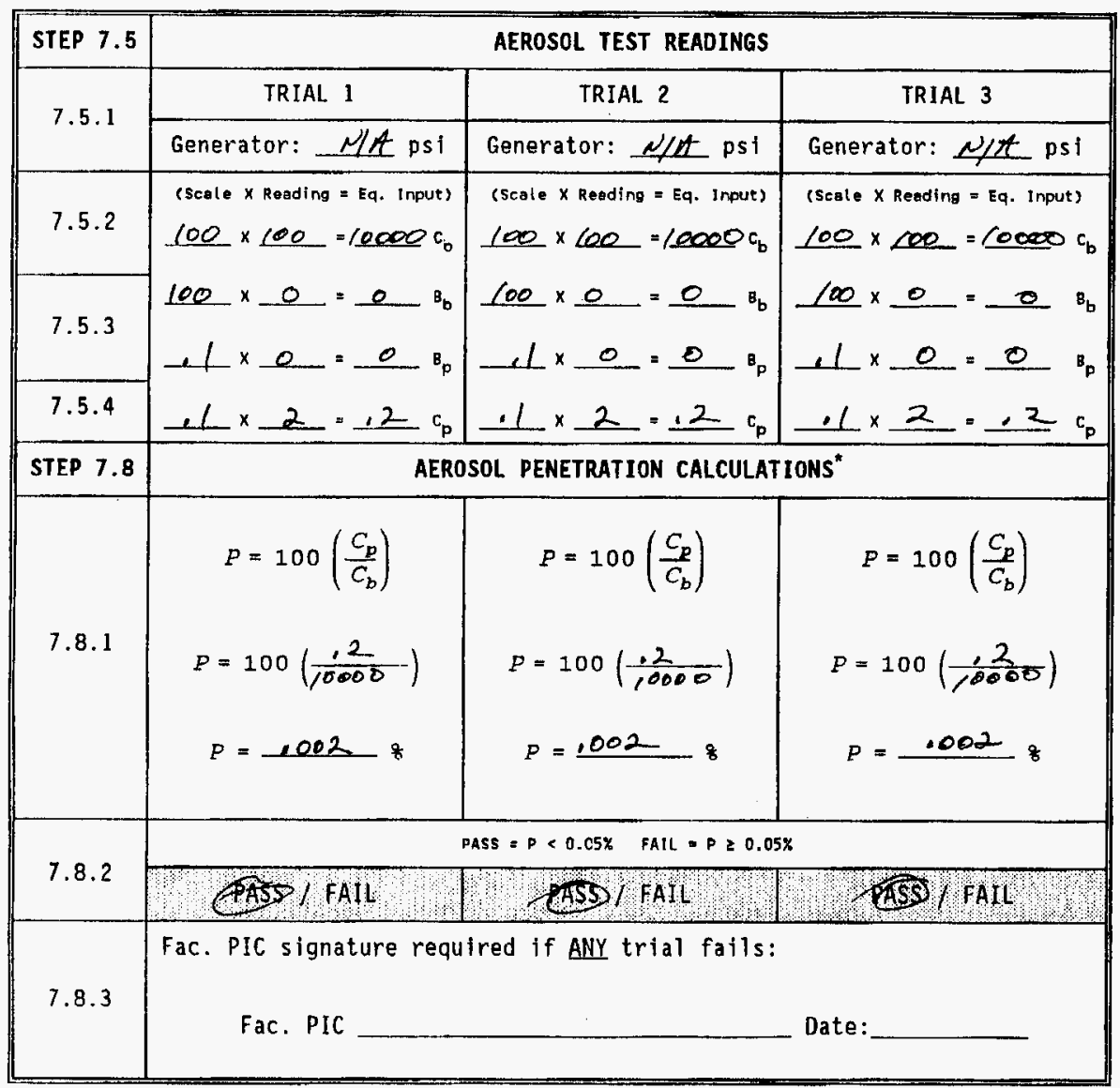

Background concentrations $\left(B_{b}, B_{p}\right)$ are for information oniy and are not part of percent penetration calculation. Initials/Date \&M $1-28-97$ 
HNF-SD-WM-0TR-215 Rev. 0

WTP MAINTENANCE PROCEDURE DATA SHEET

241-AN TANK INLET FILTER

PROC. NO. 6-TF-156-TV

AEROSOL TEST DATA SHEETS

REV. O, CHG. 0

PAGE 19 of 23

DATA SHEET 5 (Sheet 4 of 7 )

241-AN-104 TANK INLET FILTER VTP-FLT-104B

\begin{tabular}{|c|c|c|c|}
\hline STEP 7.5 & \multicolumn{3}{|c|}{ AEROSOL TEST READINGS } \\
\hline \multirow{2}{*}{7.5 .1} & TRIAL 1 & TRIAL 2 & TRIAL 3 \\
\hline & Generator: $\mu / A$ psi & Generator: $N / A$ psi & Generator: $N / A$ psi \\
\hline 7.5 .2 & $\begin{array}{l}\text { (Scale } \times \text { Reading }=\text { Eq. Input) } \\
100 \times 100=\text { LeOeO } c_{b}\end{array}$ & $\begin{array}{l}\text { (scale } \times \text { Reading }=\text { Eq. Input }) \\
100 \times 100=10000 \mathrm{c}_{\mathrm{b}}\end{array}$ & $\begin{array}{l}\text { (Scale } \times \text { Reading }=\text { Eq. Input) } \\
100 \times 100=\angle 0000 \mathrm{c}_{\mathrm{b}}\end{array}$ \\
\hline 7.5 .3 & $\begin{array}{l}100 \times-0=0 \\
11 \times 10=0\end{array}$ & $\begin{array}{l}100 \times 0=0 \\
1 \times 10=0\end{array}$ & $\begin{array}{l}100 \times 0=0 \\
11 \times 0=0\end{array}$ \\
\hline 7.5 .4 & $.1 \times 2 \times .2$ & $.1 \times 2=.2=c_{p}$ & $.1 \times \frac{2}{.2} c_{p}$ \\
\hline STEP 7.8 & \multicolumn{3}{|c|}{ AEROSOL PENETRATION CALCULATIONS } \\
\hline 7.8 .1 & $\begin{array}{c}P=100\left(\frac{C_{p}}{C_{b}}\right) \\
P=100\left(\frac{.2}{10000}\right) \\
P=.002-8\end{array}$ & $\begin{array}{c}P=100\left(\frac{C_{P}}{C_{b}}\right) \\
P=100\left(\frac{.2}{10000}\right) \\
P=1002\end{array}$ & $\begin{array}{c}P=100\left(\frac{C_{p}}{C_{b}}\right) \\
P=100\left(\frac{.3}{10000}\right) \\
P=.002\end{array}$ \\
\hline \multirow{2}{*}{7.8 .2} & \multicolumn{3}{|c|}{ PASS $=P<0.05 \% \quad$ FAlL $=P \geq 0.05 \%$} \\
\hline & CASS $7 \mathrm{FAIL}$ & RASS / FAIL & CPASS F FAIL \\
\hline 7.8 .3 & \multicolumn{3}{|c|}{ Fac. PIC signature required if ANY trial fails: } \\
\hline
\end{tabular}

* Background concentrations $\left(B_{b}, B_{p}\right)$ are for information only and are not part of percent penetration calculation. Initials/Date $\mathrm{SLC} / 28-97$ 
DATA SHEET 5 (Sheet 5 of 7)

241-AN-105 TANK INLET FILTER VTP-FLT-105B

\begin{tabular}{|c|c|c|c|}
\hline STEP 7.5 & \multicolumn{3}{|c|}{ AEROSOL TEST READINGS } \\
\hline \multirow{2}{*}{7.5 .1} & TRIAL 1 & TRIAL 2 & TRIAL 3 \\
\hline & Generator: $r / 4$ psi & Generator: $N / A$ psi & Generator: $\mu / \|^{t}$ psi \\
\hline 7.5 .2 & $\begin{array}{l}\text { (scale } \times \text { Reading }=\text { Eq. Input }) \\
100 \times 100=10000 \mathrm{c}\end{array}$ & $\begin{array}{l}\text { (scale } \times \text { Reading }=\text { Eq. Input }) \\
100 \times 100=10000 c_{b}\end{array}$ & $\begin{array}{l}\text { (Scale } \times \text { Reading }=\text { Eq. Input }) \\
100 \times 100=10000 c_{b}\end{array}$ \\
\hline 7.5 .3 & $\begin{array}{l}\angle 00 \times 00 \underline{0}{ }^{8} \mathrm{~b} \\
.11 \times \underline{0}=0\end{array}$ & $\begin{array}{l}100 \times 0=0 \\
.1 \times 0=0\end{array}$ & $\begin{array}{l}100 \times 0=0 \\
.1 \times 0=0\end{array}$ \\
\hline 7.5 .4 & $.1 \times 2=.2 c_{p}$ & $.1 \times 2=.2 c_{p}$ & $.1 \times 2=.2 c_{p}$ \\
\hline STEP 7.8 & \multicolumn{3}{|c|}{ AEROSOL PENETRATION CALCULATIONS ${ }^{*}$} \\
\hline 7.8 .1 & $\begin{array}{c}P=100\left(\frac{C_{p}}{C_{b}}\right) \\
P=100\left(\frac{.2}{10000}\right) \\
P=1002\end{array}$ & $\begin{array}{c}P=100\left(\frac{C_{p}}{C_{b}}\right) \\
P=100\left(\frac{.2}{10000}\right) \\
P=.002\end{array}$ & $\begin{array}{c}P=100\left(\frac{C_{p}}{C_{b}}\right) \\
P=100\left(\frac{.2}{1000}\right) \\
P=1002\end{array}$ \\
\hline \multirow[b]{2}{*}{7.8 .2} & \multicolumn{3}{|c|}{ PASS $=P<0.05 \% \quad$ FAIL $=P \geq 0.05 \%$} \\
\hline & CASS / FAIL & CRASS / FAIL & TASS / FAIL \\
\hline 7.8 .3 & $\begin{array}{l}\text { Fac. PIC signature requ } \\
\text { Fac. PIC }\end{array}$ & ired if ANY trial fails: & Date:_ \\
\hline
\end{tabular}

* Background concentrations $\left(B_{b}, B_{p}\right)$ are for information only and are not part of percent penetration calculation.

Initials/Date $\| 1<1-2 \%-\%$ 


\section{DATA SHEET 5 (Sheet 6 of 7)}

\section{1-AN-106 TANK INLET FILTER VTP-FLT-106B}

\begin{tabular}{|c|c|c|c|}
\hline STEP 7.5 & \multicolumn{3}{|c|}{ AEROSOL TEST READINGS } \\
\hline \multirow{2}{*}{7.5 .1} & TRIAL 1 & TRIAL 2 & TRIAL 3 \\
\hline & Generator: $N / A$ psi & Generator: $N / A$ psi & Generator: N/f psi \\
\hline 7.5 .2 & $\begin{array}{l}\text { (scale } \times \text { Reading }=\text { Eq. Input }) \\
100 \times 100=\angle 0000 \mathrm{c} b\end{array}$ & $\begin{array}{l}\text { (Scale } \times \text { Reading }=\text { Eq. Input) } \\
100 \times 10 Q=10000 \mathrm{c} b\end{array}$ & $\begin{array}{l}\text { (Scale } \times \text { Reading }=\text { Eq. Input) } \\
100 \times 100=10000 \mathrm{c}_{\mathrm{b}}\end{array}$ \\
\hline 7.5 .3 & 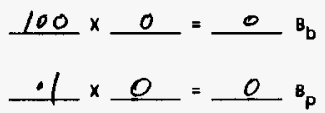 & $\begin{array}{l}\angle 00 \times \frac{0}{100}=0 . \mathrm{B}_{\mathrm{b}} \\
11 \times 0=0{ }_{\mathrm{p}}\end{array}$ & $\begin{array}{l}100 \times 10=0 \\
.1 \times 1 \mathrm{~B}_{\mathrm{b}} \\
\mathrm{B}_{\mathrm{p}}\end{array}$ \\
\hline 7.5 .4 & $11 \times \frac{2}{12} \mathrm{c}_{\mathrm{p}}$ & $11 \times 2=12 c_{p}$ & $.11 \times 2=.2 c_{p}$ \\
\hline STEP 7.8 & \multicolumn{3}{|c|}{ AEROSOL PENETRATION CALCULATIONS ${ }^{*}$} \\
\hline 7.8 .1 & $\begin{array}{c}P=100\left(\frac{C_{p}}{C_{b}}\right) \\
P=100\left(\frac{.2}{10000}\right) \\
P=1002\end{array}$ & $\begin{array}{c}P=100\left(\frac{C_{p}}{C_{b}}\right) \\
P=100\left(\frac{.2}{10000}\right) \\
P=\frac{.002}{8}\end{array}$ & $\begin{array}{c}P=100\left(\frac{C_{p}}{C_{b}}\right) \\
P=100\left(\frac{, 2}{10000}\right) \\
P=.002\end{array}$ \\
\hline \multirow{2}{*}{7.8 .2} & \multicolumn{3}{|c|}{ PASS $=P<0.05 \% \quad$ FAIL $=P \geq 0.05 \%$} \\
\hline & (PASS) FAIL & PASS 1 FAIL & GASO I FAIL \\
\hline 7.8 .3 & \multicolumn{3}{|c|}{ Fac. PIC signature required if ANY trial fails: } \\
\hline
\end{tabular}

* Background concentrations $\left(B_{b}, B_{p}\right)$ are for information only and are not part of percent penetration calculation. Initials/Date \& $1.28-97$ 


\section{DATA SHEET 5 (Sheet 7 of 7)}

241-AN-107 TANK INLET FILTER VTP-FLT-107B

\begin{tabular}{|c|c|c|c|}
\hline STEP 7.5 & \multicolumn{3}{|c|}{ AEROSOL TEST READINGS } \\
\hline \multirow{2}{*}{7.5 .1} & TRIAL 1 & TRIAL 2 & TRIAL 3 \\
\hline & Generator: $N / A$ psi & Generator: $N / A$ psi & Generator: $\psi / h A$ psi \\
\hline 7.5 .2 & $\begin{array}{l}\text { (scale } \times \text { Reading }=\text { Eq. Inpur }) \\
100 \times 100=10000 c_{b}\end{array}$ & $\begin{array}{l}\text { (scale } \times \text { Reading }=\text { Eq. Input) } \\
100 \times 100=10000 \mathrm{c}_{\mathrm{b}}\end{array}$ & $\begin{array}{l}\text { (Scale } \times \text { Reading }=\text { Eq. Input }) \\
100 \times 100=10000 c_{b}\end{array}$ \\
\hline 7.5 .3 & $\begin{array}{l}100 \times \underline{0}=0 . B_{b} \\
-11 \times 0=0\end{array}$ & $\begin{array}{l}100 \times 0=0 \\
.1 \times \underline{0}=0\end{array}$ & $\begin{array}{l}100 \times \underline{0}=0 . \mathrm{B}_{\mathrm{b}} \\
.1 \times \underline{0}=\underline{\mathrm{B}_{\mathrm{p}}}\end{array}$ \\
\hline 7.5 .4 & $.1 \times 2=.2 c_{p}$ & $.1 \times 2 \times .2 c_{p}$ & $11 \times 2=, 2 c_{p}$ \\
\hline STEP 7.8 & \multicolumn{3}{|c|}{ AEROSOL PENETRATION CALCULATIONS ${ }^{*}$} \\
\hline 7.8 .1 & $\begin{array}{c}P=100\left(\frac{C_{p}}{C_{b}}\right) \\
P=100\left(\frac{, 2}{0.000}\right) \\
P=, 002\end{array}$ & $\begin{array}{c}P=100\left(\frac{C_{p}}{C_{b}}\right) \\
P=100\left(\frac{.2}{10000}\right) \\
P=. .0028\end{array}$ & $\begin{array}{c}P=100\left(\frac{C_{P}}{C_{b}}\right) \\
P=100\left(\frac{+2}{10000}\right) \\
P=.002\end{array}$ \\
\hline \multirow[b]{2}{*}{7.8 .2} & \multicolumn{3}{|c|}{ PASS $=P<0.05 \% \quad$ FAIL $=P \geq 0.05 \%$} \\
\hline & CAAS / FAIL & TASS I FAIL & CASS / FAIL \\
\hline 7.8 .3 & \multicolumn{3}{|c|}{$\begin{array}{l}\text { Fac. PIC signature required if ANY trial fails: } \\
\text { Fac. PIC _ Date: }\end{array}$} \\
\hline
\end{tabular}

* Background concentrations $\left(B_{b}, B_{p}\right)$ are for information only and are not part of percent penetration calculation.

Initials/Date Se/ $1-28 \mathrm{gl}$ 
HNF-SD-WM-0TR-215 Rev. 0

WTP MAINTENANCE PROCEDURE DATA SHEET

241-AN TANK INLET FILTER

PROC. NO. 6-TF-156-TV

AEROSOL TEST DATA SHEETS

REV. O, CHG. O

PAGE 23 of 23

\section{DATA SHEET 6}

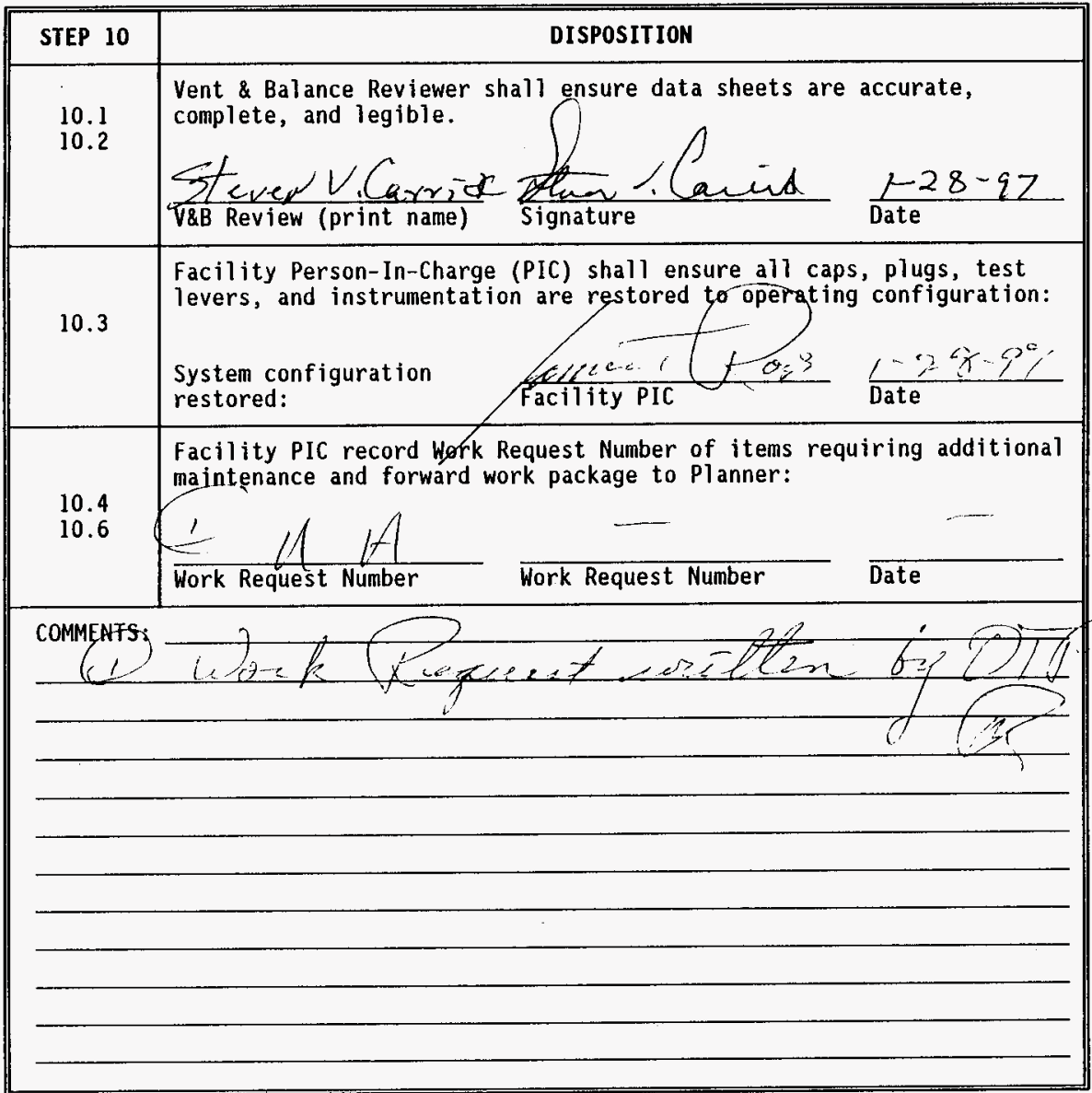




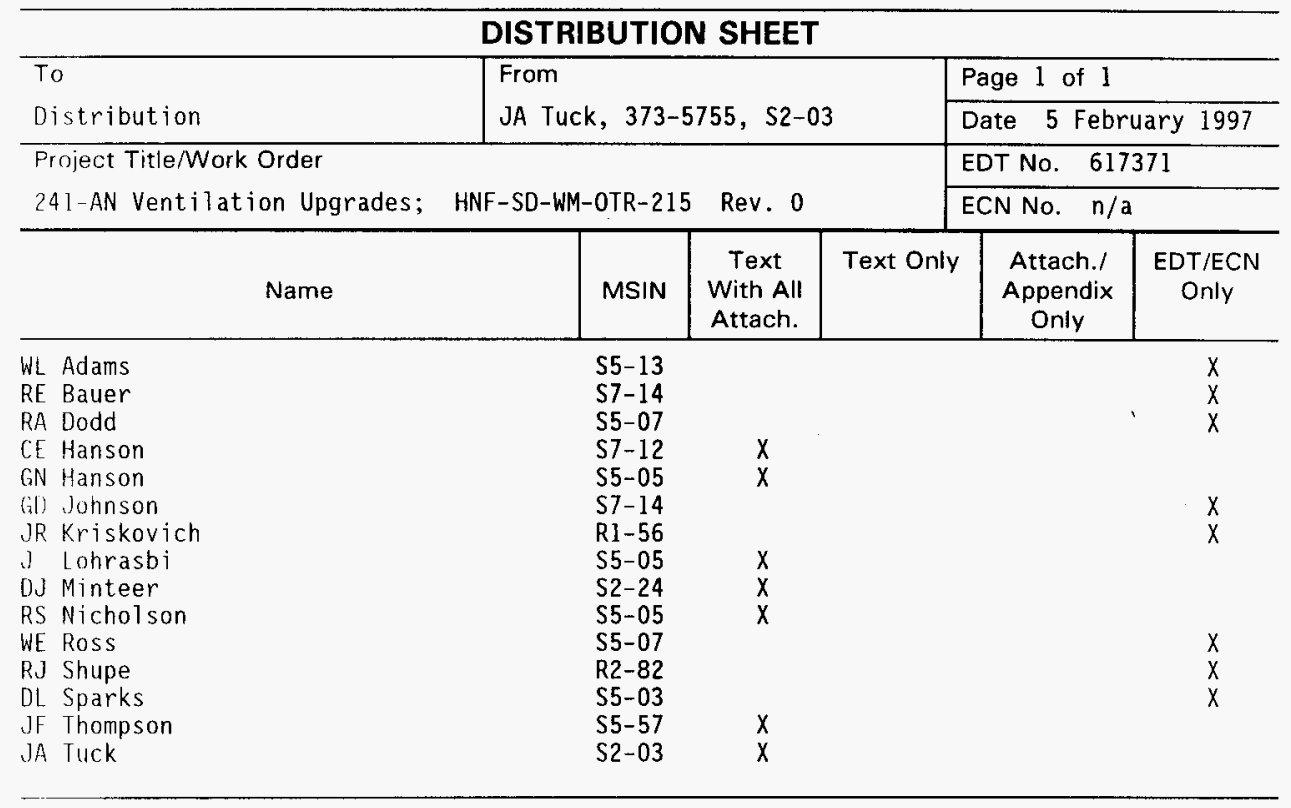

